\title{
DOE-NE Light Water Reactor Sustainability Program and EPRI Long-Term Operations Program - Joint Research and Development Plan
}

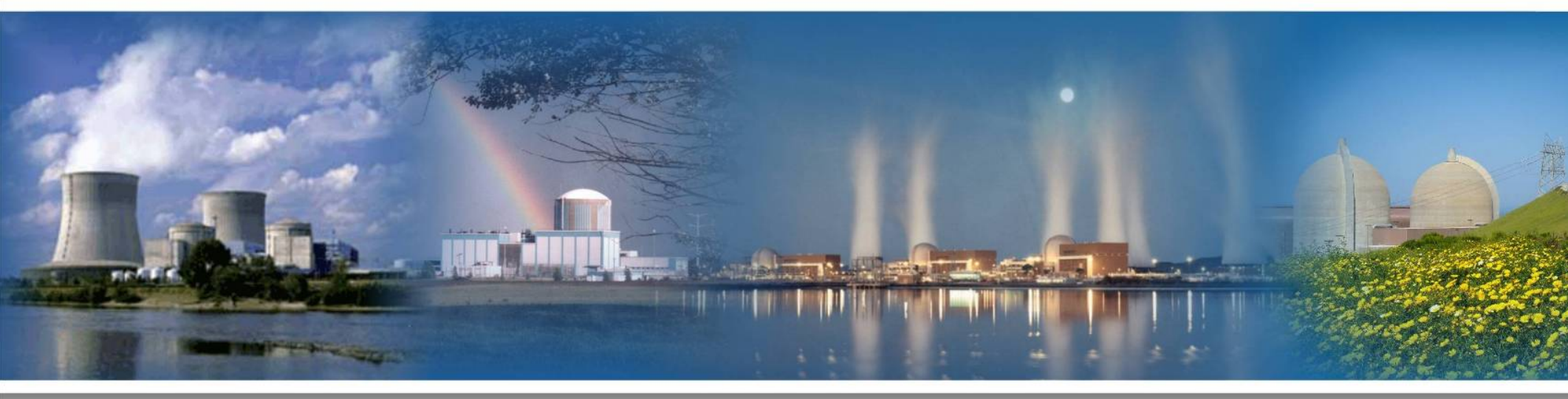

April 2012

DOE Office of Nuclear Energy 


\section{DISCLAIMER}

This information was prepared as an account of work sponsored by an agency of the U.S. Government. Neither the U.S. Government nor any agency thereof, nor any of their employees, makes any warranty, expressed or implied, or assumes any legal liability or responsibility for the accuracy, completeness, or usefulness, of any information, apparatus, product, or process disclosed, or represents that its use would not infringe privately owned rights. References herein to any specific commercial product, process, or service by trade name, trade mark, manufacturer, or otherwise, do not necessarily constitute or imply its endorsement, recommendation, or favoring by the U.S. Government or any agency thereof. The views and opinions of authors expressed herein do not necessarily state or reflect those of the U.S. Government or any agency thereof. 
INL/EXT-12-24562

Revision 1

\title{
DOE-NE Light Water Reactor Sustainability Program and EPRI Long-Term Operations Program - Joint Research and Development Plan
}

April 2012

\author{
Idaho National Laboratory \\ Idaho Falls, Idaho 83415
}

http://www.inl.gov

Prepared for the

U.S. Department of Energy

Office of Nuclear Energy

Under DOE Idaho Operations Office

Contract DE-AC07-05ID14517 

DOE-NE Light Water Reactor Sustainability Program and EPRI Long-Term Operations Program - Joint Research and Development Plan

Revision 1

April 2012

Approved by

Kathy, McCarty

Light Water Reactor Sustainability Technical Integration Office Director, INL

Rill $a$. Rent

Richard Keister

Light Water Reactor Sustainability Federal Program Director, DOE-NE

$\frac{4-11-12}{\frac{4 / 11 / 12}{\text { Date }}}$

Sherry Bernhoft

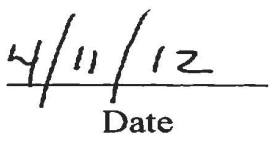





\section{SUMMARY}

Nuclear power has contributed almost $20 \%$ of the total amount of electricity generated in the United States over the past two decades. High capacity factors and low operating costs make nuclear power plants (NPPs) some of the most economical power generators available. Further, nuclear power remains the single largest contributor (nearly $70 \%$ ) of non-greenhouse gas-emitting electric power generation in the United States. Even when major refurbishments are performed to extend operating life, these plants continue to represent cost-effective, low-carbon assets to the nation's electrical generation capability.

Nine commercial NPPs in the Unites States have passed their 40th anniversary of power operations, and about one-half of the existing fleet will reach the same 40-year mark within the next decade. While recent performance has been excellent (capacity factors approaching or exceeding 90\%), the fleet is facing a number of technical challenges related to long-term operation. Those challenges include uncertainties in material safety margins and degradation rates under extended operating conditions, obsolescence of instrumentation and control systems, safety analysis methods that would benefit from updating, and others. A regulatory process exists (10 CFR Part 54) for obtaining approval from the U.S. Nuclear Regulatory Commission on extended NPP operations beyond 60 years. However, the U.S. Nuclear Regulatory Commission will require plants applying for license renewals to extend NPP service life to demonstrate that adequate design and operational safety margins will be maintained over the duration of the extended operations period.

If current NPPs do not operate beyond 60 years (due to owner decisions or regulatory restrictions), the total fraction of domestic electrical energy generated from nuclear power will begin to decline - even with the expected addition of new nuclear generating capacity. Replacing these units will require long-lead planning periods (10 to 15 years prior to unit retirement). In addition, significant capital investments (hundreds of billions of dollars) will be needed to design, construct, and commission the replacement generation capacity. Further, if the new capacity has to meet any carbon-neutral criteria (i.e., the replacement units must not produce more greenhouse gas emissions than the units being retired), the costs for replacement generation capacity will be even higher.

Recognizing the challenges associated with pursuing commercial NPP operations beyond 60 years, the U.S. Department of Energy's (DOE) Office of Nuclear Energy (NE) and the Electric Power Research Institute (EPRI) have established separate but complementary research and development programs (DOE-NE's Light Water Reactor Sustainability [LWRS] Program and EPRI's Long-Term Operations [LTO]Program) to address these challenges. To ensure that a proper linkage is maintained between the programs, DOE-NE and EPRI executed a Memorandum of Understanding in late 2010 to "establish guiding principles under which research activities (between LWRS and LTO) could be coordinated to the benefit of both parties." The Memorandum of Understanding calls for DOE-NE and EPRI to "provide and annually update a coordinated plan for the LWRS and LTO programs. The plan should provide for the integration of the separate LWRS and LTO Program Plans at the project level, showing project 
scope, schedule, budgets, and key interrelationships between the LWRS and LTO programs, including possible cost sharing." This document represents the first annual revision to the initial version (March 2011) of the plan as called for in the Memorandum of Understanding. 


\section{CONTENTS}

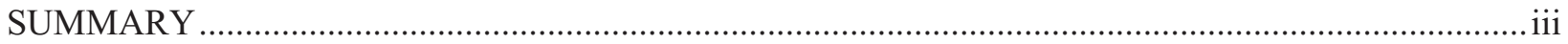

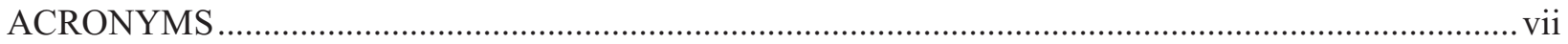

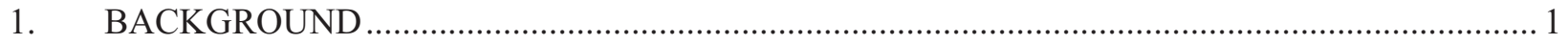

$1.1 \quad$ U.S. Department of Energy Office of Nuclear Energy.................................................... 1

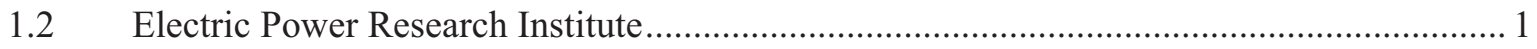

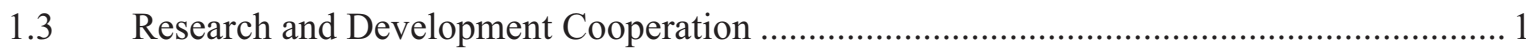

2. DESCRIPTION OF RESEARCH AND DEVELOPMENT PROGRAMS …............................... 3

2.1 Department of Energy Office of Nuclear Energy Light Water Reactor Sustainability

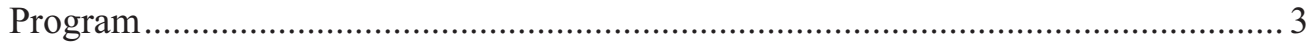

2.2 Electric Power Research Institute Long-Term Operations Program ................................. 4

2.3 Reporting of Research and Development Projects ....................................................... 7

3. LIGHT WATER REACTOR SUSTAINABILITY/LONG-TERM OPERATIONS COORDINATED RESEARCH AND DEVELOPMENT ACTIVITIES .................................... 11

4. LIGHT WATER REACTOR SUSTAINABILITY/LONG-TERM OPERATIONS COLLABORATIVE RESEARCH AND DEVELOPMENT ACTIVITIES. 


\section{ACRONYMS}

CMC ceramic matrix composite

DOE-NE U.S. Department of Energy, Office of Nuclear Energy

EPRI Electric Power Research Institute

IASCC irradiation-assisted stress corrosion cracking

I\&C instrumentation and control

II\&C instrumentation, information, and control

IMT Issues Management Table

INL Idaho National Laboratory

LTO long-term operations

LWR light water reactor

LWRS light water reactor sustainability

MDM Materials Degradation Matrix

NDE nondestructive examination

NPP nuclear power plant

NRC U.S. Nuclear Regulatory Commission

R\&D research and development

RISMC risk-informed safety margin characterization

RPV reactor pressure vessel

$\mathrm{SiC} \quad$ silicon carbide

SSC systems, structures, and components 


\section{DOE-NE Light Water Reactor Sustainability Program and EPRI Long-Term Operations Program - Joint Research and Development Plan}

1. BACKGROUND

\subsection{U.S. Department of Energy Office of Nuclear Energy}

The U.S. Department of Energy, Office of Nuclear Energy (DOE-NE) conducts research and development $(\mathrm{R} \& \mathrm{D})$ on nuclear energy to advance nuclear power as a resource capable of meeting the United States' energy, environmental, and energy security needs by resolving technical, cost, safety, proliferation resistance, and security barriers through research, development, and demonstration activities, as appropriate. R\&D efforts under the Light Water Reactor Sustainability (LWRS) Program are managed by DOE-NE's Office of Light Water Reactor Technologies, NE-72, and the program Technical Integration Office, located at the Idaho National Laboratory (INL).

\subsection{Electric Power Research Institute}

The Electric Power Research Institute (EPRI) conducts R\&D in the public's interest, mostly with funding provided by its membership and the electric utility industry, with respect to the production, transmission, distribution, and utilization of electric power, including research designed to improve the safety, reliability, and economy of nuclear power plants (NPPs). R\&D efforts in the Long-Term Operations (LTO) Program are managed as a separate technical program operating in the Plant Technology Department of the EPRI Nuclear Power Sector with the guidance of an industry advisory Integration Committee.

\subsection{Research and Development Cooperation}

Because both DOE-NE and EPRI conduct R\&D in technologies that have application to establishing the feasibility of operating commercial light water reactors (LWRs) beyond the current 60 -year license limits, it is important that the work be coordinated to the benefit of both organizations. An integrated approach to the planning and execution of this R\&D will enable both DOE-NE and EPRI to more efficiently establish and fund research efforts and avoid unnecessary duplication of efforts.

In October 2010, DOE-NE and EPRI executed a memorandum of understanding to "establish guiding principles under which research activities (between LWRS and LTO) could be coordinated to the benefit of both parties." The primary focus of the memorandum of understanding is on R\&D goals, objectives, and tasks identified and discussed in the following documents:

1. Strategic Plan for LWR R\&D, jointly prepared by EPRI and INL for DOE-NE in November 2007 (this report has been superseded by the DOE-NE R\&D Roadmap and the implementation plans for each R\&D objective discussed on the roadmap)

2. Life Beyond 60 Workshop Summary Report, documenting a workshop jointly conducted by the U.S. Nuclear Regulatory Commission (NRC) and DOE on February 19 through 21, 2008 (a second workshop was held in February 2011) 
3. The DOE-NE Light Water Reactor Sustainability Research and Development Program Plan, dated December 2009 (superseded by the Light Water Reactor Sustainability Program Integrated Program Plan, January 2012)

4. The EPRI LTO Strategic Plan, dated June 13, 2010 (most recent update: July 2011).

Although both programs emerged from the November 2007 LWR R\&D Strategic Plan, each program proceeded with development of individual program plans and more detailed R\&D plans for individual technology pathways or projects. Still, both programs continue to cooperate on a range of R\&D activities related to extended plant operations. Cooperation includes the sharing of responsibilities (leadership and financial) for conducting portions of large, multi-year R\&D projects; the exchange of information on R\&D work in areas of mutual interest; and participation (by either the LWRS Technical Integration Office Director or the LTO Manager) in periodic conference calls and meetings (technical and budget reviews) for the other program.

The work funded and managed by DOE under the LWRS Program is laid out along the following R\&D pathways:

1. Materials Aging and Degradation

2. Advanced Light Water Reactor Nuclear Fuels

3. Advanced Instrumentation, Control, and Information (II\&C) Systems Technologies

4. Risk-Informed Safety Margin Characterization (RISMC).

The work funded and managed by EPRI under their LTO Program is organized and managed in the following work areas:

1. Primary System Metals Aging

2. Concrete Structures, including Containment Degradation

3. Instrumentation and Control (I\&C) and Information Technology (including online monitoring of critical equipment)

4. Advanced Safety and Risk Analysis Tools

5. Integrated Life-Cycle Management (data, methods, and tools)

6. Advanced Fuel Analysis and Design for Existing Plants (in Calendar Year 2012 there are no active projects in this work area)

7. Cable Aging

8. $\quad$ Aging Management Program Scope for Operation Beyond 60 Years

9. Integrated Strategy, Process Plan, and Demonstration Plants.

As acknowledged in the memorandum of understanding, "the technical areas above encompassing each participant's work scope are roughly the same;" that is, both organizations have the same objectives to deliver technology on critical issues in a timely manner to inform decisions on life extension and 
license renewal beyond 60 years. LTO Technical Area 5, Integrated Life-Cycle Management, and LTO Technical Area 8, Aging Management Program Scope, currently are exceptions for which there are no corresponding LWRS Pathways. In a few cases, activities are highly collaborative and co-funded — both organizations fund the same activity with the same deliverable. However, in most cases, as stated in the memorandum of understanding, "...the planned work in each program is distinctly different as the result of planning that reduces duplication of effort and takes into account each party's interests and strengths."

At the center of DOE's interest is work to develop new scientific knowledge, models, tools, and technology. DOE brings the strong expertise of national laboratory investigators, unique laboratory capabilities, and relationships with universities and other laboratories. At the center of EPRI's interest are the adaptation, validation, and implementation of technology with deliverables such as databases, guidelines, and pilot applications. EPRI brings global leadership in conducting public interest R\&D with collaboration from nuclear utilities. Through joint planning and defined cooperation, the intent is to leverage the diversity between LWRS and LTO to more efficiently and effectively meet the joint objectives.

\section{DESCRIPTION OF RESEARCH AND DEVELOPMENT PROGRAMS}

\subsection{Department of Energy Office of Nuclear Energy Light Water Reactor Sustainability Program}

Sustainability in the context of LWRs is defined as the ability to maintain safe and economic operation of the existing fleet of NPPs for a longer-than-initially-licensed lifetime. It has two facets with respect to long-term operations: (1) manage aging of hardware so the NPP lifetime can be extended and the plant can continue to operate safely, efficiently, and economically; and (2) provide science-based solutions to industry to implement technology to exceed the performance of the current labor-intensive business model.

In April 2010, DOE-NE's R\&D Roadmap was issued. The roadmap organized DOE-NE activities in accordance with four objectives that ensure nuclear energy remains a compelling and viable energy option for the United States. Objective 1 of the roadmap focuses on developing the technologies and other solutions that can improve reliability, sustain safety, and extend life of the current fleet of commercial NPPs. The LWRS Program is the primary programmatic activity that addresses Objective 1 . The LWRS Program is focused on the following three goals:

1. Developing the fundamental scientific basis to understand, predict, and measure changes in materials and systems, structures, and components (SSCs) as they age in environments associated with continued long-term operations of existing reactors

2. Applying this fundamental knowledge to develop and demonstrate methods and technologies that support safe and economical long-term operation of existing reactors

3. Researching new technologies to address enhanced plant performance, economics, and safety.

Programmatically, the LWRS Program depends on a sequence of four successful phases:

(1) a utility's decision to invest in extending NPP life beyond 60 years; (2) regulatory and public confidence in NPP life extension; (3) implementation of NPP refurbishments and upgrades to meet licensing and enhanced performance requirements; and (4) safe and economic NPP operation for the intended period of the NPP life extension. While tightly coupled, each of the four sequential phases is 
critical to nuclear power generation on its own and with a specific set of challenges. The four phases span several decades, a feature important for planning and implementation of the supporting R\&D program.

Through the LWRS Program, DOE collaborates with industry and NRC in appropriate ways to support and conduct the long-term research needed to inform major component refurbishment and replacement strategies, performance enhancements, plant license extensions, and age-related regulatory oversight decisions. The DOE role focuses on aging phenomena and issues that require long-term research and are generic to reactor type. Cost-shared demonstration activities will be conducted when appropriate.

The LWRS Program consists of the following four primary technical areas of R\&D:

1. Materials Aging and Degradation with R\&D to develop the scientific basis for understanding and predicting long-term environmental degradation behavior of materials in NPPs. The work will provide data and methods to assess the performance of SSCs essential to safe and sustained NPP operations. The R\&D products will be used to define operational limits and aging mitigation approaches for materials in NPP SSCs that are subject to long-term operating conditions.

2. Advanced LWR Nuclear Fuels with R\&D to improve the scientific knowledge basis for understanding and predicting fundamental nuclear fuel and cladding performance in NPPs and applying this information to development of high-performance, high burn-up fuels with improved safety, cladding integrity, and improved nuclear fuel-cycle economics. The R\&D products will be used to deploy new fuel/core designs for the existing NPP fleet with improved safety and economic operational capabilities.

3. Advanced II\&C Systems Technologies with R\&D to address long-term aging and modernization of current I\&C technologies through development/testing of new I\&C technologies and advanced condition monitoring technologies for more automated and reliable plant operation. The R\&D products will be used to design and deploy new II\&C technologies and systems in existing NPPs that provide an enhanced understanding of plant operating conditions and available margins and improved response strategies and capabilities for operational events.

4. RISMC develops and deploys approaches to support management of uncertainty in safety margins quantification to improve decision making for NPPs. This pathway will (1) develop and demonstrate a risk-assessment method tied to safety margins quantification and (2) create advanced tools for safety assessment that enable more accurate representation of an NPP safety margin. The R\&D products will be used to produce state-of-the-art NPP safety analysis information that yields new insights on actual plant safety/operational margins.

\subsection{Electric Power Research Institute Long-Term Operations Program}

High capacity factors and low operating costs make NPPs some of the most economical power generators available. Even when major plant components must be upgraded to extend operating life, these plants often represent a cost-effective, low-carbon asset. The decision to extend NPP life involves interrelated technical, economic, regulatory, and public policy issues. Unknown or uncertain technical inputs impact the decision-making process both directly and indirectly: directly through design and operational contingencies and indirectly through impacts on regulatory actions and public policy. 
Recognizing the many technical challenges confronting NPP operation, EPRI launched the LTO Project in 2009. LTO is defined as being high-performance NPP operation to 60 years, 80 years, or beyond. High performance is measured by reliability, availability, cost of operations, and safety.

The LTO Project at EPRI is justified by the potential benefits that long-term operations present to society and to member companies. In 2011, the EPRI LTO Project was elevated to Program status and is funded by all EPRI Nuclear Sector members. However, success is contingent on timely and useful products. LTO products must provide a sound technical basis for decisions necessary to achieve high-performance NPP operation to 60 years, 80 years, or beyond. Specifically, LTO Program projects must address one or more of the following:

1. License renewal beyond 60 years

2. Aging management and life-cycle management throughout long-term operation

3. Refurbishment and uprate decisions

4. Opportunities for modernization and performance improvement.

Criteria for selecting technical areas and specific work scopes within technical areas are as follows:

1. Projects address one or more of the following needs:

a. Identify and characterize (or dismiss) a potential life-limiting issue

b. Support aging management and life-cycle management

c. Provide opportunities for modernization and uprate

d. Develop enabling technology (e.g., analysis methods) that will be needed to enhance performance or reduce cost.

2. Useful results are planned for the timeframe of 2014 to 2019.

3. It is unlikely that the planned R\&D would be performed within other programs at EPRI.

4. EPRI involvement is necessary to provide industry input to R\&D efforts with collaborating partners such as DOE LWRS or NRC's Office of Nuclear Regulatory Research.

The R\&D portfolio addresses the following nine technical areas and associated principal objectives:

1. For primary system metals, characterize the conditions and parameters associated with aging degradation, develop data resources and predictive models for remaining useful life, and provide methods to mitigate risk and extend component life. Individual projects addressing this objective include the following:

a. Extension of Materials Degradation Matrix (MDM) and Issues Management Tables (IMTs) to include Failure Mechanisms to 80 Years 
b. Evaluation of Crack Initiation and Propagation Mechanisms in LWR Components

c. Identifying Mechanisms and Mitigation Strategies for Irradiation-Assisted Stress Corrosion Cracking of Stainless Steel in LWR Core Components

d. Reactor Pressure Vessel Embrittlement from Long-Term Fluence

e. Welding of Irradiated Materials for Reactor Internals Repair and Replacement.

2. For concrete structures, including containment, identify and prioritize degradation mechanisms and locations, establish methods for issue resolution, including new nondestructive examination and forensic concrete examination methods, prognostic modeling to determine remaining useful life, and investigate mitigation measures for issues important to long-term operations.

3. Through support of structured pilot studies, demonstrate and document advanced I\&C and information technology to address obsolescence aging of components and systems. Pilot studies will address highly integrated control room, highly automated plant, integrated operations, human performance improvement for field workers, outage safety and efficiency, and centralized online monitoring and information integration. EPRI will participate on a working group that oversees these studies. EPRI also will document good practices and requirements for these studies into an accessible database. For mature applications with generic applicability, EPRI will develop guidelines for future applications.

4. Create advanced safety and risk analysis tools to address anticipated needs during the period of long-term operation and develop an approach for best estimate safety margins assessments that can identify the contributions of design and operational changes, aging effects, and key uncertainties.

5. Provide industry with integrated life-cycle management data, methods, and tools for key components that will improve the cost and certainty of high-performance operation and will support optimization of integrated refurbishment and uprate plans. Individual projects addressing this objective include the following:
a. Integrated Life-Cycle Management Data Resource and Method
b. Pilot Application of EDF Asset Management Tools
c. Identification and Assessment of Potential Life-Limiting Issues.

6. Support the investigation of silicon carbide $(\mathrm{SiC})$ fuel cladding designs and reliability analyses that can lead to breakthroughs in the cost or performance of fuel in existing plants. Current work is specifically addressing technical barriers and potential benefits to the use of SiC fuel cladding.

7. Develop the technical basis for aging management and life-cycle management of cables; specifically, identifying cable aging management activities, classes of cables that can be life limiting, and data and methods for life-cycle management of aging cables. Enhanced testing and end-of-life predictive methods will be investigated. 
8. Investigate aging management program scope for operation beyond 60 years. Research results and operating experience might identify additional components of concern, failure mechanisms, or conditions that would be part of aging management programs for operation beyond 60 years. $\mathrm{R} \& \mathrm{D}$ activities will be identified where risk-important gaps exist for aging management activities, including time-limited aging assessments, one-time inspections, and periodic inspections or monitoring.

9. Develop an integrated strategy, process plan, and demonstration plants to support license renewal, the decision to extend operation beyond 60 years, and life-cycle management of assets. Demonstration plants will pilot applications of monitoring methods, inspection guidelines, testing methods, demonstrations of new technologies, and analyses. The principal projects addressing this objective are as follows:

\section{a. LTO Integration and Collaboration \\ b. Nuclear Plant Life-Extension Demonstration Project.}

In addition, a "living" IMT maintains the status of all identified issues and their priorities. This IMT is regularly reviewed for accuracy and completeness by stakeholders at EPRI, LWRS representatives, a working group of the Nuclear Energy Institute, and EPRI advisors. The objectives and associated projects listed in this document have been selected from high-priority issues in the IMT that meet the selection criteria and have received concurrence of the LTO Integration Committee.

\subsection{Reporting of Research and Development Projects}

Consistent with the memorandum of understanding, the R\&D projects described in the LWRS and LTO program plans are presented in the following section of this joint plan using the following categories:

1. Section 3 discusses "Coordinated (but independent) Activities," meaning that "in general, work in the category will be managed by either DOE or EPRI, using standard, approved processes for R\&D management. Funding is also likely to be independent for work in this category. Coordination will be limited to joint planning and communications to limit possible overlaps and gaps that may exist in the planned activities."

2. Section 4 discusses "Collaborative Activities," meaning that "DOE and EPRI intend work in the category to be planned and executed on a collaborative basis. The collaborative efforts between DOE and EPRI may involve, to a significant degree, joint funding as permitted by law and available appropriations. DOE and EPRI will determine which organization will lead each effort based on which party is positioned to most efficiently and effectively execute the work."

Sections 3 and 4 provide a brief summary of the R\&D activities. The work of the lead program for the R\&D activity is described first, followed by a similar description of the work by the supporting program (in some cases, the lead for the activity is jointly shared by the LWRS Program and the LTO Program).

\footnotetext{
a As committed to in the memorandum of understanding, "DOE and EPRI endeavor to plan, integrate, and prioritize nuclear R\&D in Coordinated Activities and Collaborative Activities, and intend to keep each other informed of meetings, correspondence, and the status of work in order to strengthen the partnership." Further, the LWRS and LTO Programs are committed to maintaining an inventory of the relevant technical results from these R\&D projects and sharing each program's R\&D results with the other organization.
} 
Table 1 represents a summary overview of the joint R\&D plan. The table lists (beginning in the left column) the LWRS Program's R\&D activities and the corresponding (coordinated or collaborative) LTO Program's R\&D activities. To provide more perspective on the total scope of R\&D work, the table also identifies LWRS and LTO projects that do not meet the memorandum of understanding criteria for coordinated or collaborative activities. Details on those R\&D projects can be found in the individual LWRS and LTO program R\&D plans. For the purposes of this plan, multiple R\&D activities are, in selected instances, rolled up under a single heading.

Table 1. Summary overview of the joint research and development plan.

\begin{tabular}{|c|c|c|c|c|}
\hline LWRS Project & Related LTO Project & $\begin{array}{c}\text { Coordinated } \\
\text { Activity }\end{array}$ & $\begin{array}{c}\text { Collaborative } \\
\text { Activity }\end{array}$ & $\begin{array}{l}\text { Program } \\
\text { Unique } \\
\text { Activity } \\
\end{array}$ \\
\hline $\begin{array}{l}\text { Materials Aging and } \\
\text { Degradation }\end{array}$ & $\begin{array}{l}\text { Understanding, } \\
\text { Prediction, and } \\
\text { Mitigation of Primary } \\
\text { System Aging } \\
\text { Degradation }\end{array}$ & & & \\
\hline $\begin{array}{l}\text { Expanded Proactive } \\
\text { Materials Degradation } \\
\text { Analysis }\end{array}$ & MDM and IMTs & & $\begin{array}{l}\text { LWRS-LTO } \\
\text { joint lead }\end{array}$ & \\
\hline \multicolumn{5}{|l|}{ Reactor Metals } \\
\hline $\begin{array}{l}\text { Mechanisms of } \\
\text { Irradiation-Assisted Stress } \\
\text { Corrosion Cracking } \\
\text { (IASCC) } \\
\text { Reactor Vessel Internals }\end{array}$ & $\begin{array}{l}\text { IASCC: Identifying } \\
\text { Mechanisms and } \\
\text { Mitigation Strategies } \\
\text { for IASCC of Austenitic } \\
\text { Steels and LWR Core } \\
\text { Components }\end{array}$ & & $\begin{array}{l}\text { LWRS-LTO } \\
\text { joint lead }\end{array}$ & \\
\hline $\begin{array}{l}\text { Reactor Pressure Vessel } \\
\text { (RPV) }\end{array}$ & $\begin{array}{l}\text { RPV Embrittlement } \\
\text { from Long-Term } \\
\text { Fluence }\end{array}$ & LWRS lead & & \\
\hline $\begin{array}{l}\text { Crack Initiation in Ni-Based } \\
\text { Alloys }\end{array}$ & $\begin{array}{l}\text { Environmental-Assisted } \\
\text { Cracking: Evaluation of } \\
\text { Crack Initiation and } \\
\text { Propagation } \\
\text { Mechanisms in LWR } \\
\text { Components }\end{array}$ & $\begin{array}{l}\text { LWRS-LTO } \\
\text { joint lead }\end{array}$ & & \\
\hline Concrete & $\begin{array}{l}\text { Comprehensive Aging } \\
\text { Management of } \\
\text { Concrete Structures } \\
\text { (Technology Roadmap) }\end{array}$ & & LTO lead & \\
\hline Cabling & $\begin{array}{l}\text { Technical Basis for } \\
\text { Aging Management and } \\
\text { Life-Cycle Management } \\
\text { of Cables }\end{array}$ & $\begin{array}{l}\text { LWRS-LTO } \\
\text { joint lead }\end{array}$ & & \\
\hline
\end{tabular}




\begin{tabular}{|c|c|c|c|c|}
\hline LWRS Project & Related LTO Project & $\begin{array}{c}\text { Coordinated } \\
\text { Activity }\end{array}$ & $\begin{array}{c}\text { Collaborative } \\
\text { Activity }\end{array}$ & $\begin{array}{l}\text { Program } \\
\text { Unique } \\
\text { Activity } \\
\end{array}$ \\
\hline \multicolumn{5}{|l|}{ Mitigation Strategies } \\
\hline Weld Repair Techniques & $\begin{array}{l}\text { Advanced Welding } \\
\text { Methods for Irradiated } \\
\text { Materials }\end{array}$ & & $\begin{array}{l}\text { LWRS-LTO } \\
\text { joint lead }\end{array}$ & \\
\hline $\begin{array}{l}\text { Thermal (Post-Irradiation) } \\
\text { Annealing }\end{array}$ & & & & $\begin{array}{l}\text { LWRS } \\
\text { lead }\end{array}$ \\
\hline $\begin{array}{l}\text { Advanced Replacement } \\
\text { Alloys and Fabrication } \\
\text { Techniques }\end{array}$ & & & & $\begin{array}{l}\text { LWRS } \\
\text { lead }\end{array}$ \\
\hline $\begin{array}{l}\text { Integrated Research - } \\
\text { International Activities } \\
\text { (Halden Project, } \\
\text { International Forum on } \\
\text { Reactor Aging } \\
\text { Management) }\end{array}$ & $\begin{array}{l}\text { Participation in } \\
\text { International Forum on } \\
\text { Reactor Aging } \\
\text { Management }\end{array}$ & LWRS Lead & & \\
\hline $\begin{array}{l}\text { Integrated Research - } \\
\text { International Activities } \\
\text { (Materials Aging Institute) }\end{array}$ & $\begin{array}{l}\text { Partnership in Materials } \\
\text { Aging Institute (EPRI } \\
\text { Nuclear Sector) }\end{array}$ & LTO Lead & & \\
\hline $\begin{array}{l}\text { Constellation } \\
\text { Demonstration Project }\end{array}$ & $\begin{array}{l}\text { Ginna and Nine Mile } \\
\text { Point-1 Demonstration } \\
\text { Plant Activities }\end{array}$ & & $\begin{array}{l}\text { LWRS-LTO } \\
\text { joint lead }\end{array}$ & \\
\hline $\begin{array}{l}\text { Zion Materials Management } \\
\text { and Coordination }\end{array}$ & & & & $\begin{array}{l}\text { LWRS } \\
\text { lead }\end{array}$ \\
\hline $\begin{array}{l}\text { Nondestructive } \\
\text { Examination (NDE) } \\
\text { Technologies }\end{array}$ & $\begin{array}{l}\text { Opportunities to } \\
\text { Employ NDE } \\
\text { Technologies for } \\
\text { Automatic, Continuous, } \\
\text { In-situ Monitoring }\end{array}$ & $\begin{array}{l}\text { LWRS-LTO } \\
\text { joint lead }\end{array}$ & & \\
\hline \multicolumn{5}{|l|}{$\begin{array}{l}\text { Advanced Light Water } \\
\text { Reactor Fuels }\end{array}$} \\
\hline $\begin{array}{l}\text { Advanced Design Concepts } \\
\text { (SiC Cladding Design and } \\
\text { Testing) }\end{array}$ & $\begin{array}{l}\text { SiC Fuel Cladding } \\
\text { Design and Reliability } \\
\text { Analyses }\end{array}$ & LWRS lead & & \\
\hline Halden Project & & & & $\begin{array}{l}\text { LWRS } \\
\text { lead }\end{array}$ \\
\hline $\begin{array}{l}\text { Mechanistic Understanding } \\
\text { of Fuel Behavior }\end{array}$ & & & & $\begin{array}{l}\text { LWRS } \\
\text { lead }\end{array}$ \\
\hline $\begin{array}{l}\text { Advanced Design and } \\
\text { Measurement Tools }\end{array}$ & & & & $\begin{array}{l}\text { LWRS } \\
\text { lead }\end{array}$ \\
\hline
\end{tabular}




\begin{tabular}{|c|c|c|c|c|}
\hline LWRS Project & Related LTO Project & $\begin{array}{c}\text { Coordinated } \\
\text { Activity }\end{array}$ & $\begin{array}{c}\text { Collaborative } \\
\text { Activity }\end{array}$ & $\begin{array}{l}\text { Program } \\
\text { Unique } \\
\text { Activity } \\
\end{array}$ \\
\hline \multicolumn{5}{|l|}{$\begin{array}{l}\text { Advanced II\&C Systems } \\
\text { Technologies }\end{array}$} \\
\hline $\begin{array}{l}\text { New Instrumentation and } \\
\text { Control and Human System } \\
\text { Interfaces and Capabilities } \\
\text { (including Advanced II\&C } \\
\text { Pilot Projects) }\end{array}$ & $\begin{array}{l}\text { Requirements Database } \\
\text { and Guidelines for } \\
\text { Advanced I\&C, Human } \\
\text { System Interface, and } \\
\text { Information Technology }\end{array}$ & & LWRS lead & \\
\hline Halden Project & & LWRS lead & & \\
\hline $\begin{array}{l}\text { Centralized Online } \\
\text { Monitoring and Information } \\
\text { Integration } \\
\text { In-Situ Continuous } \\
\text { Monitoring for Degradation }\end{array}$ & $\begin{array}{l}\text { Centralized Online } \\
\text { Monitoring } \\
\text { Methodology, } \\
\text { Guidelines, and Pilot } \\
\text { Studies (Part of } \\
\text { Advanced II\&C Pilot } \\
\text { Projects) }\end{array}$ & & LTO lead & \\
\hline $\begin{array}{l}\text { Industrial and Regulatory } \\
\text { Engagement }\end{array}$ & $\begin{array}{l}\text { Requirements Database } \\
\text { and Guidelines for } \\
\text { Advanced I\&C, Human } \\
\text { System Interface, and } \\
\text { Information Technology }\end{array}$ & & LTO lead & \\
\hline \multicolumn{5}{|l|}{ RISMC } \\
\hline \multirow[t]{2}{*}{$\begin{array}{l}\text { Margins Analysis } \\
\text { Techniques } \\
\text { Modeling and Simulation } \\
\text { Activities }\end{array}$} & $\begin{array}{l}\text { Enhanced Safety } \\
\text { Analysis Capability }\end{array}$ & & $\begin{array}{l}\text { LWRS-LTO } \\
\text { joint lead }\end{array}$ & \\
\hline & $\begin{array}{l}\text { Enhanced Risk } \\
\text { Assessment and } \\
\text { Management Capability }\end{array}$ & LTO lead & & \\
\hline \multicolumn{5}{|l|}{ Other Projects } \\
\hline & $\begin{array}{l}\text { Aging Management } \\
\text { Program Scope for } \\
\text { Operation Beyond } 60 \\
\text { Years }\end{array}$ & & & LTO Lead \\
\hline & $\begin{array}{l}\text { Alternative Cooling } \\
\text { Strategies }\end{array}$ & & & $\begin{array}{l}\text { EPRI work } \\
\text { outside } \\
\text { LTO scope }\end{array}$ \\
\hline & $\begin{array}{l}\text { Case Studies for Large, } \\
\text { Integrated Plant } \\
\text { Refurbishments }\end{array}$ & & & $\begin{array}{l}\text { EPRI work } \\
\text { outside } \\
\text { LTO scope }\end{array}$ \\
\hline
\end{tabular}




\section{LIGHT WATER REACTOR SUSTAINABILITY/LONG-TERM OPERATIONS COORDINATED RESEARCH AND DEVELOPMENT ACTIVITIES}

\begin{tabular}{|c|c|}
\hline R\&D Area & $\begin{array}{c}\text { Materials Aging and Degradation (LWRS)/Understanding, Prediction, and } \\
\text { Mitigation of Primary System Aging Degradation (LTO) }\end{array}$ \\
\hline \multicolumn{2}{|l|}{ Reactor Metals } \\
\hline \multirow[t]{3}{*}{ LWRS - RPV } & R\&D Scope and Objectives: \\
\hline & $\begin{array}{l}\text { High-Fluence Effects on RPV Steels - Irradiation of RPV steels may cause } \\
\text { embrittlement of the primary reactor vessel. Both industrial capsules and single } \\
\text { variable experiments may be required to evaluate potential for embrittlement and } \\
\text { to provide a better mechanistic understanding of this form of degradation. This } \\
\text { effort also provides an opportunity for early programmatic success and can build } \\
\text { on past efforts. Testing will include impact and fracture toughness evaluations, } \\
\text { hardness, and microstructural analysis. }\end{array}$ \\
\hline & $\begin{array}{l}\text { Effects of Using Supplementary Alloys of High-Flux Irradiation on RPV Steels - } \\
\text { New methods to generate meaningful data out of previously tested specimens } \\
\text { will be developed. Embrittlement margins for a vessel can be accurately } \\
\text { calculated using supplementary alloys and experiments such as higher flux test } \\
\text { reactors. The potential for non-conservative estimates resulting from these } \\
\text { methodologies must be evaluated to fully understand the potential influence on } \\
\text { safety margins. Critical assessments and benchmark experiments will be } \\
\text { conducted. }\end{array}$ \\
\hline \multirow{2}{*}{$\begin{array}{l}\text { LTO - RPV } \\
\text { Embrittlement from } \\
\text { Long-Term Fluence }\end{array}$} & R\&D Scope and Objectives: \\
\hline & $\begin{array}{l}\text { Currently, the considerations of materials degradation for } 60 \text { years of operation } \\
\text { do not include the fluence effect on RPV embrittlement as a life-limiting factor } \\
\text { because of the relatively low fluence level. However, for } 80 \text { or more years, } \\
\text { refinement of analysis, testing, and validation using irradiated samples will be } \\
\text { needed. This project will design, fabricate, and irradiate a supplemental } \\
\text { surveillance capsule that will provide high-fluence irradiated data and will } \\
\text { develop and refine an embrittlement trend correlation using the Master Curve } \\
\text { approach to convert the shift in Charpy V-notch energy data at different } \\
\text { temperatures and irradiations to a fracture toughness equivalent shift. This } \\
\text { embrittlement trend correlation is necessary to bridge the gap between the } \\
\text { Charpy V-notch energy evaluation approach and the fracture toughness Master } \\
\text { Curve approach. In addition, there is a need to develop new testing methods to } \\
\text { extend the use of existing surveillance specimens to generate Master Curve } \\
\text { fracture toughness data. This project will participate in a round robin test } \\
\text { program to assess one such method that has been developed. }\end{array}$ \\
\hline
\end{tabular}




\begin{tabular}{|c|c|}
\hline R\&D Area & $\begin{array}{c}\text { Materials Aging and Degradation (LWRS)/Understanding, Prediction, and } \\
\text { Mitigation of Primary System Aging Degradation (LTO) }\end{array}$ \\
\hline \multirow[t]{5}{*}{ LWRS - RPV } & $\begin{array}{l}\text { Milestones: } \\
\text { - Deliver mechanistic understanding for key materials and degradation } \\
\text { modes, including the following: }\end{array}$ \\
\hline & $\begin{array}{l}\text { (2015) Deliver the final model to predict RPV embrittlement over a } \\
\text { variety of conditions for extended service (e.g., time, temperature, } \\
\text { composition, flux, and fluence) together with all supporting research } \\
\text { data. }\end{array}$ \\
\hline & $\begin{array}{l}\text { - Issue a final report on RPV attenuation and surrogate material issues } \\
\text { (experimental results for replacement materials, attenuation studies, } \\
\text { potential implications on operation and surveillance, and revisions to } \\
\text { the RPV model). }\end{array}$ \\
\hline & $\begin{array}{l}\text { (2017 to 2021) Deliver model capability for the key materials issues, } \\
\text { including the following: }\end{array}$ \\
\hline & $\begin{array}{l}\text { - Develop additional modeling capabilities of RPV (substitute } \\
\text { materials and attenuation and extending utility and accuracy). }\end{array}$ \\
\hline \multirow{2}{*}{$\begin{array}{l}\text { LTO - RPV } \\
\text { Embrittlement from } \\
\text { Long-Term Fluence }\end{array}$} & Milestones: \\
\hline & $\begin{array}{l}\text { This project involves irradiation of supplemental surveillance specimens to high } \\
\text { fluence in a pressurized water reactor. The follow-up testing and analysis must } \\
\text { be performed in a laboratory with the capability of handling irradiated materials. } \\
\text { The project requires } 10 \text { or more years to complete the work. The work will be } \\
\text { coordinated with on-going and planned work within the Pressurized Water } \\
\text { Reactor Materials Reliability Program and Boiling Water Reactor Vessel and } \\
\text { Internals Project to address RPV embrittlement after extended operation. } \\
\text { - (December 2014) Design, fabricate, and insert a supplemental surveillance } \\
\text { capsule in a host pressurized water reactor. } \\
\text { (2014) Develop and refine an embrittlement trend correlation; report on } \\
\text { revisions to embrittlement trend correlation. } \\
\text { (2013) Participate in a round robin test of a new method to extend the use } \\
\text { of existing surveillance specimens to generate Master Curve data. }\end{array}$ \\
\hline $\begin{array}{l}\text { LWRS - Crack } \\
\text { Initiation in } \\
\text { Ni-Based Alloys }\end{array}$ & $\begin{array}{l}\text { R\&D Scope and Objectives: } \\
\text { Identify underlying mechanisms of stress corrosion cracking in Ni-based alloys. } \\
\text { Understanding and modeling the mechanisms of crack-initiation is a key step in } \\
\text { predicting and mitigating stress corrosion cracking in the primary and secondary } \\
\text { water circuits. An examination into the influence of surface conditions on } \\
\text { precursor states and crack initiation also is a key need for Ni-based alloys and } \\
\text { austenitic stainless steels. This effort would include crack-growth rate testing of } \\
\text { Ni-based alloys and stainless steels in simulated LWR water chemistries. } \\
\text { Carefully controlled microstructure and surface states will be used to generate } \\
\text { single variable experiments. The experimental effort in this task will be highly } \\
\text { complementary to efforts being initiated at the Materials Aging Institute (EPRI } \\
\text { being a member), which are focused primarily on modeling of crack initiation. }\end{array}$ \\
\hline
\end{tabular}




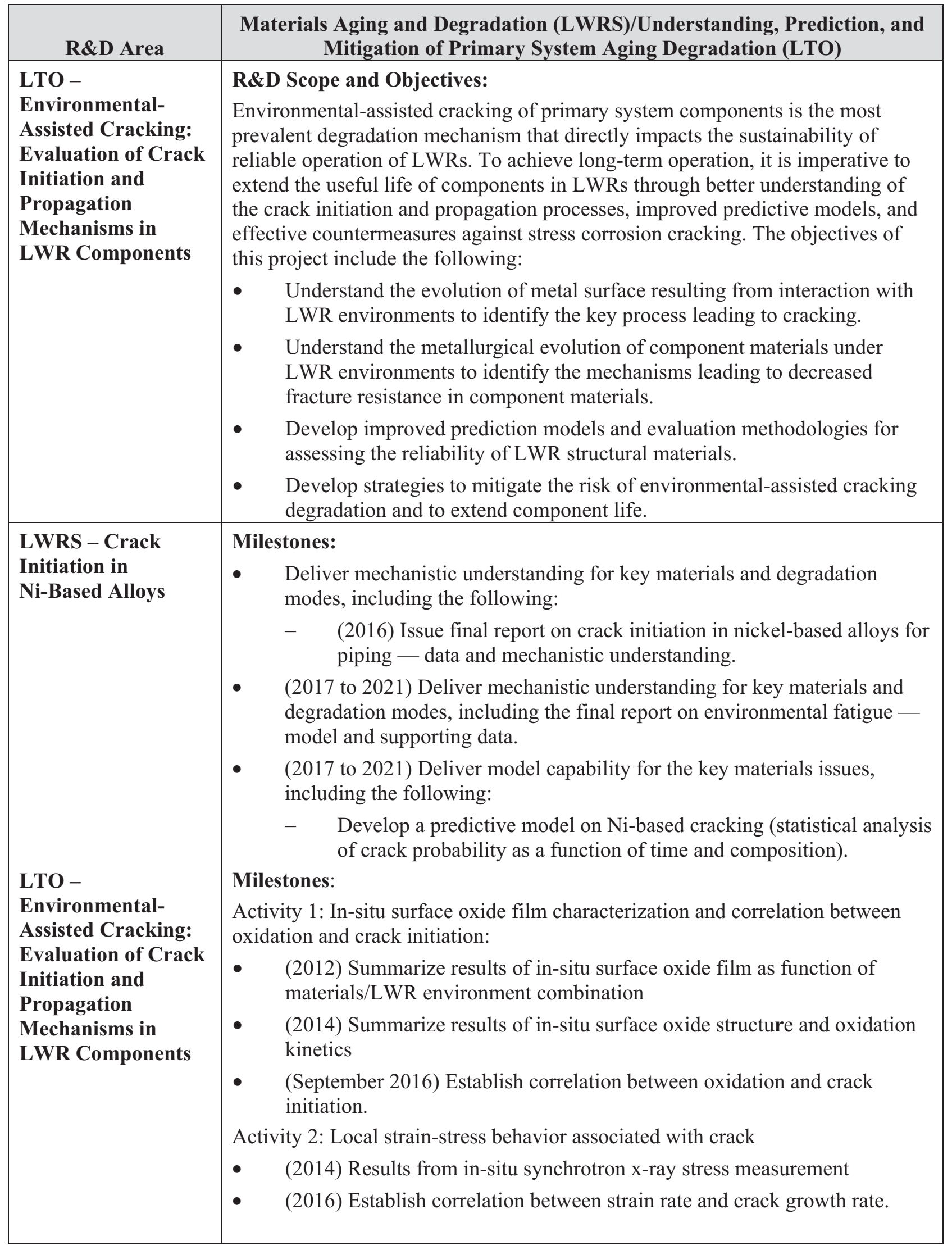




\begin{tabular}{|c|c|}
\hline R\&D Area & $\begin{array}{c}\text { Materials Aging and Degradation (LWRS)/Understanding, Prediction, and } \\
\text { Mitigation of Primary System Aging Degradation (LTO) }\end{array}$ \\
\hline & $\begin{array}{l}\text { Activity 3: Parametric study and development of mitigation strategy } \\
\text { - } \\
\text { (2015) Summary of parametric experiments on crack growth rate } \\
\text { - }(2017) \text { Develop and validate mitigation strategies. } \\
\text { Activity 4: Modeling } \\
\text { - } \\
\text { (2016) Environmental-assisted cracking crack growth prediction model } \\
\text { (September 2019) Environmental-assisted cracking crack initiation model. } \\
\text { Activity 5: Consolidation of Knowledge Base for Long-Term Operations } \\
\text { - } \\
\text { (2013, 2015, and 2018) Environmental-assisted cracking knowledge base } \\
\text { updates for long term operations. }\end{array}$ \\
\hline \multicolumn{2}{|l|}{ Cabling } \\
\hline LWRS - Cabling & $\begin{array}{l}\text { R\&D Scope and Objectives: } \\
\text { Cable aging is a concern that currently faces the operators of existing NPPs. The } \\
\text { plant operators carry out periodic cable inspections using NDE techniques to } \\
\text { measure degradation and determine when replacement is needed. Degradation of } \\
\text { these cables is primarily caused by long-term exposure to high temperatures. } \\
\text { Additionally, stretches of cables that have been buried underground are } \\
\text { frequently exposed to groundwater. Wholesale replacement of cables would } \\
\text { likely be a "show stopper" for plant operation beyond } 60 \text { years because of the } \\
\text { cost and difficulty in replacement. } \\
\text { One of the primary activities for cable aging research in the LWRS Program } \\
\text { involves identification of mechanisms of cable degradation to provide } \\
\text { understanding of the role of composition, history, and the environment on cable } \\
\text { insulation degradation; understanding of accelerated testing limitations; and } \\
\text { support to partners in modeling activities, surveillance, and testing criteria. This } \\
\text { task will provide experimental characterization of key forms of cable and cable } \\
\text { insulation in a cooperative effort with NRC and EPRI. Tests will include } \\
\text { evaluations of cable integrity following exposure to elevated temperature, } \\
\text { humidity, ionizing irradiation, or a combination of these environmental elements. } \\
\text { These experimental data will be used to evaluate mechanisms of cable aging and } \\
\text { determine the validity or limitations of accelerated aging protocols. The } \\
\text { experimental data and mechanistic studies can be used to help identify key } \\
\text { operational variables related to cable aging, optimize inspection and maintenance } \\
\text { schedules to the most susceptible materials/locations, and, in the long-range, } \\
\text { design tolerant materials. }\end{array}$ \\
\hline LTO - Advanced & R\&D Scope and Objectives: \\
\hline $\begin{array}{l}\text { Cable Testing } \\
\text { Technology for Life- } \\
\text { Cycle Management } \\
\text { of Cables }\end{array}$ & $\begin{array}{l}\text { Develop the technical basis for aging management and life-cycle management of } \\
\text { cable systems.* Specifically, identifying cable system aging management } \\
\text { activities, the portions of the cable system having limited life, and data and } \\
\text { methods for life-cycle management of aging cable systems. Enhanced testing and } \\
\text { end-of-life predictive methods will be investigated. Completion of technical basis } \\
\text { is expected to frame R\&D funding needs to resolve identified issues. } \\
\text { * Cable systems include the field cables, their terminations and splices, and local wiring, as well as } \\
\text { the support and protective systems such as trays, conduits, and ducts. }\end{array}$ \\
\hline
\end{tabular}




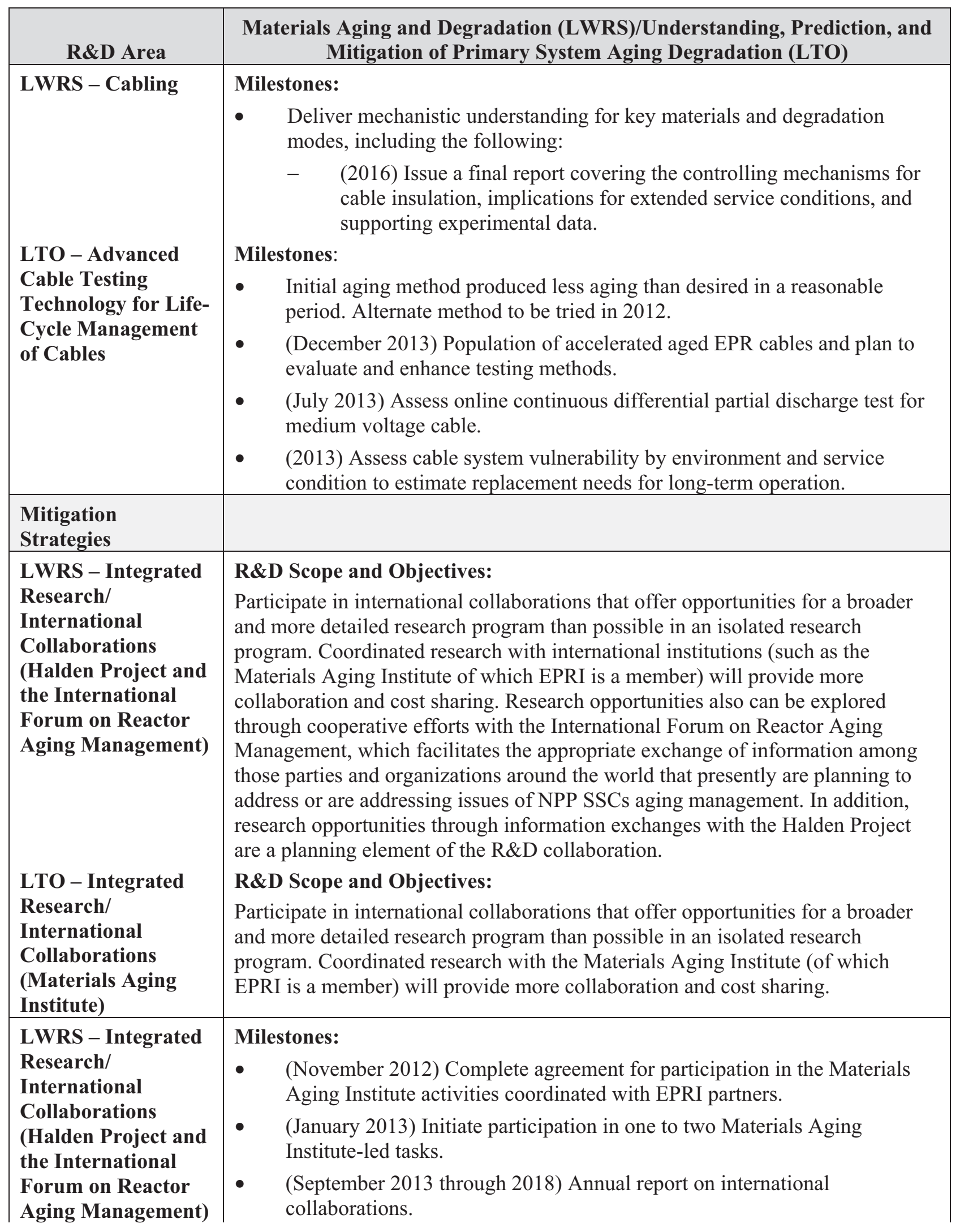




\begin{tabular}{|c|c|}
\hline R\&D Area & $\begin{array}{c}\text { Materials Aging and Degradation (LWRS)/Understanding, Prediction, and } \\
\text { Mitigation of Primary System Aging Degradation (LTO) }\end{array}$ \\
\hline $\begin{array}{l}\text { LTO - Integrated } \\
\text { Research/ } \\
\text { International } \\
\text { Collaborations } \\
\text { (Materials Aging } \\
\text { Institute) }\end{array}$ & $\begin{array}{l}\text { Milestones } \\
\text { - (2012) Participate in the International Forum on Reactor Aging } \\
\text { Management meetings and activities. } \\
\text { (November 2012) Complete agreement for participation in the Materials } \\
\text { Aging Institute activities coordinated with the LWRS Program. }\end{array}$ \\
\hline $\begin{array}{l}\text { LTO - Constellation } \\
\text { Demonstration } \\
\text { Project }\end{array}$ & 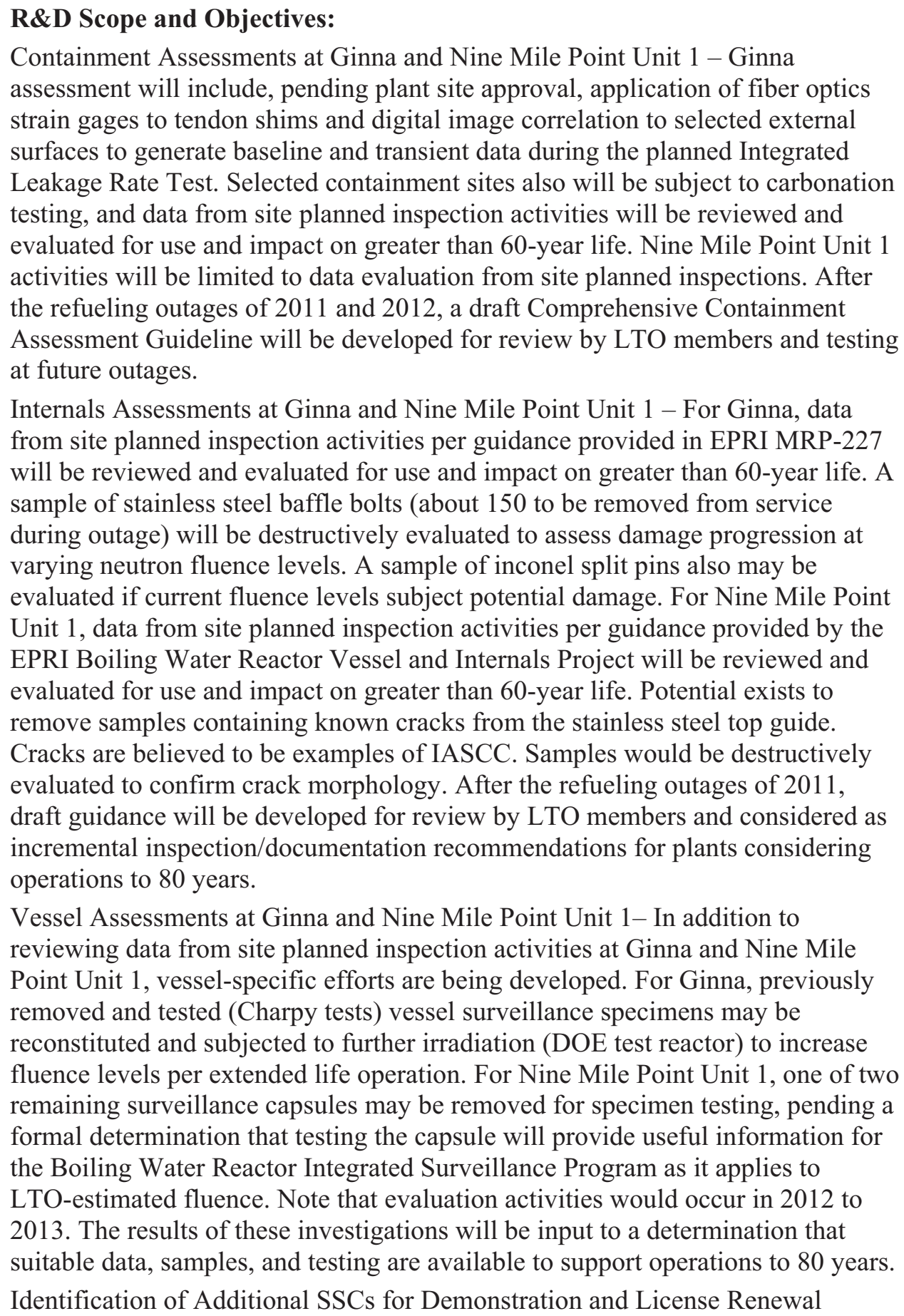 \\
\hline
\end{tabular}




\begin{tabular}{|c|c|}
\hline R\&D Area & $\begin{array}{c}\text { Materials Aging and Degradation (LWRS)/Understanding, Prediction, and } \\
\text { Mitigation of Primary System Aging Degradation (LTO) }\end{array}$ \\
\hline $\begin{array}{l}\text { LWRS - } \\
\text { Constellation } \\
\text { Demonstration } \\
\text { Project }\end{array}$ & $\begin{array}{l}\text { Technical Issues -NRC is interested in this demonstration project and direct } \\
\text { participation is a potential in } 2011 \text { and beyond. The focus of this effort will be on } \\
\text { supporting the Nuclear Energy Institute and NRC on developing a template for } \\
\text { license extension submittals to NRC. Work activities and results at both Ginna } \\
\text { and Nine Mile Point Unit } 1 \text { will be reviewed to identify and pursue opportunities } \\
\text { to improve life assessment efforts for other critical SSCs (e.g., cabling, spent fuel } \\
\text { pool, and secondary piping) expected to be considered in extended-life license } \\
\text { applications. } \\
\text { R\&D Scope and Objectives: } \\
\text { The Constellation Pilot Project is a joint venture between the LWRS Program, } \\
\text { EPRI, and the Constellation Energy Nuclear Group. The project utilizes two of } \\
\text { Constellation's nuclear stations (R. E. Ginna and Nine Mile Point 1) for research } \\
\text { opportunities to support future licensing of NPPs. Specific areas of joint research } \\
\text { have included development of a concrete inspection guideline, installation of } \\
\text { equipment for monitoring containment rebar and concrete strain, and additional } \\
\text { analysis of RPV surveillance coupons. Opportunities for additional and } \\
\text { continued collaboration will be explored in coming years. }\end{array}$ \\
\hline $\begin{array}{l}\text { LTO - Constellation } \\
\text { Demonstration } \\
\text { Project }\end{array}$ & 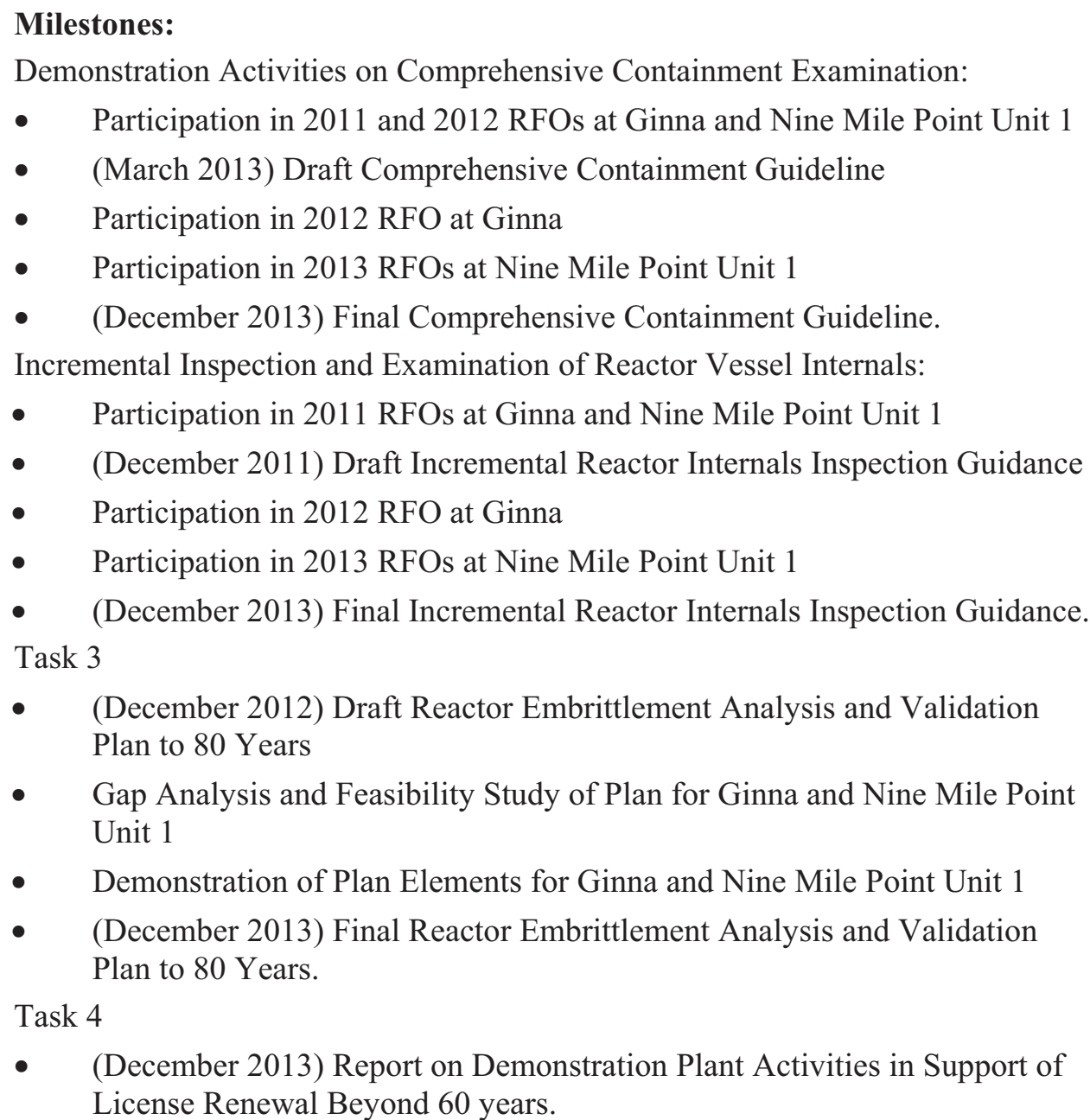 \\
\hline
\end{tabular}




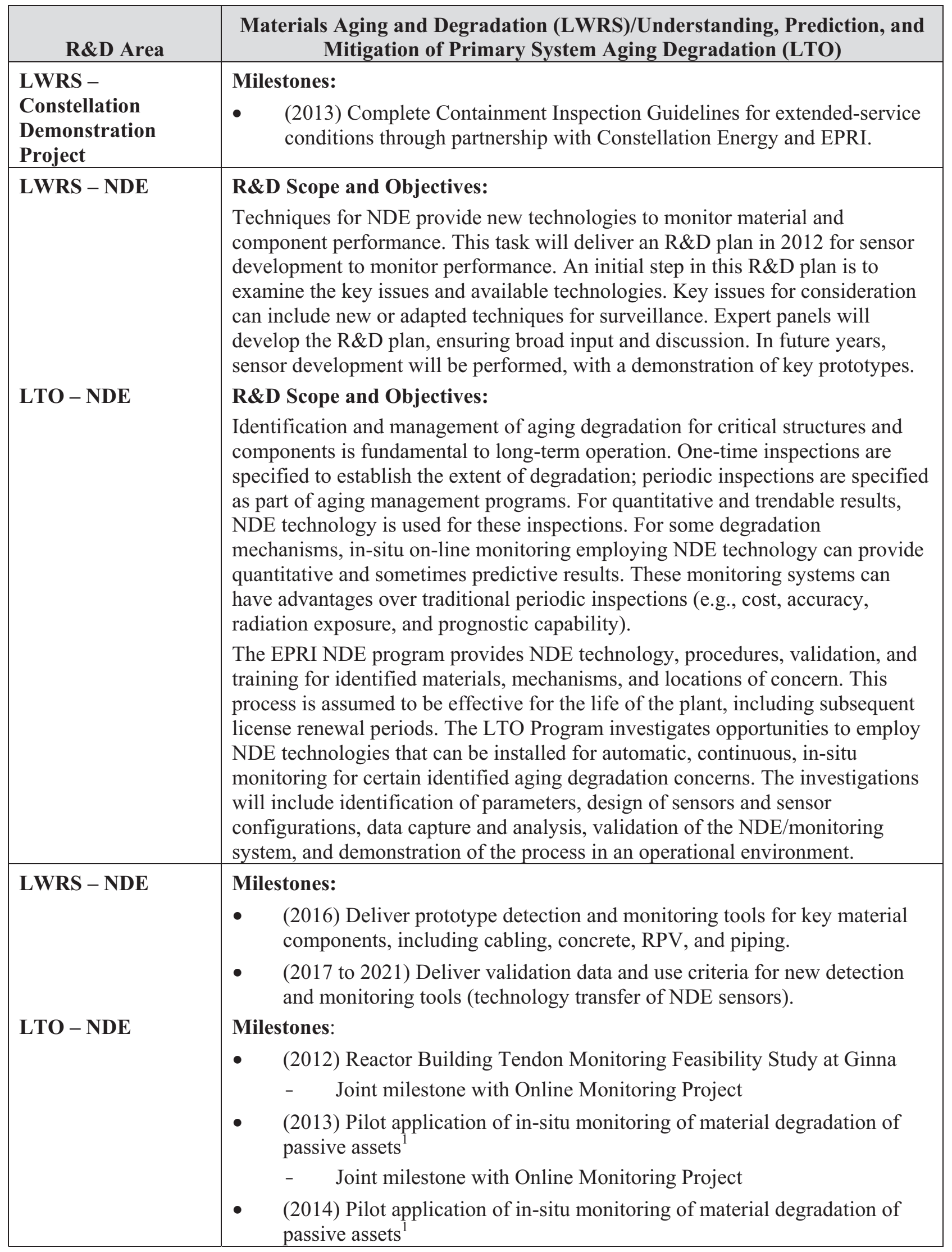




\begin{tabular}{|l|c|}
\hline R\&D Area & $\begin{array}{c}\text { Materials Aging and Degradation (LWRS)/Understanding, Prediction, and } \\
\text { Mitigation of Primary System Aging Degradation (LTO) }\end{array}$ \\
\hline & $\begin{array}{c}\text { Joint milestone with Online Monitoring Project } \\
1 \text { At least one pilot application will employ NDE technology as part of the } \\
\text { monitoring system. }\end{array}$ \\
\hline
\end{tabular}

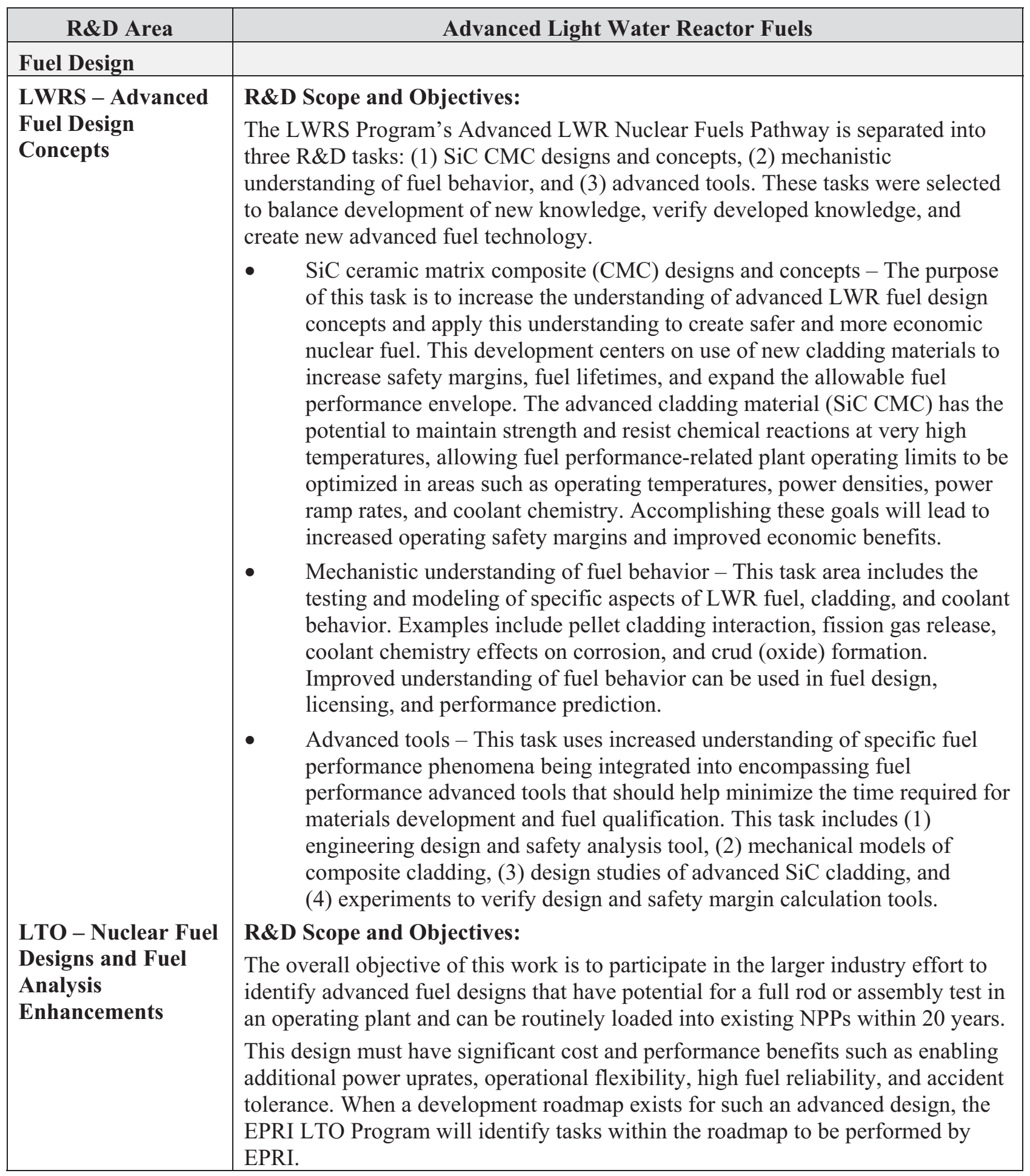




\begin{tabular}{|c|c|}
\hline R\&D Area & Advanced Light Water Reactor Fuels \\
\hline $\begin{array}{l}\text { LWRS - Advanced } \\
\text { Fuel Design } \\
\text { Concepts }\end{array}$ & 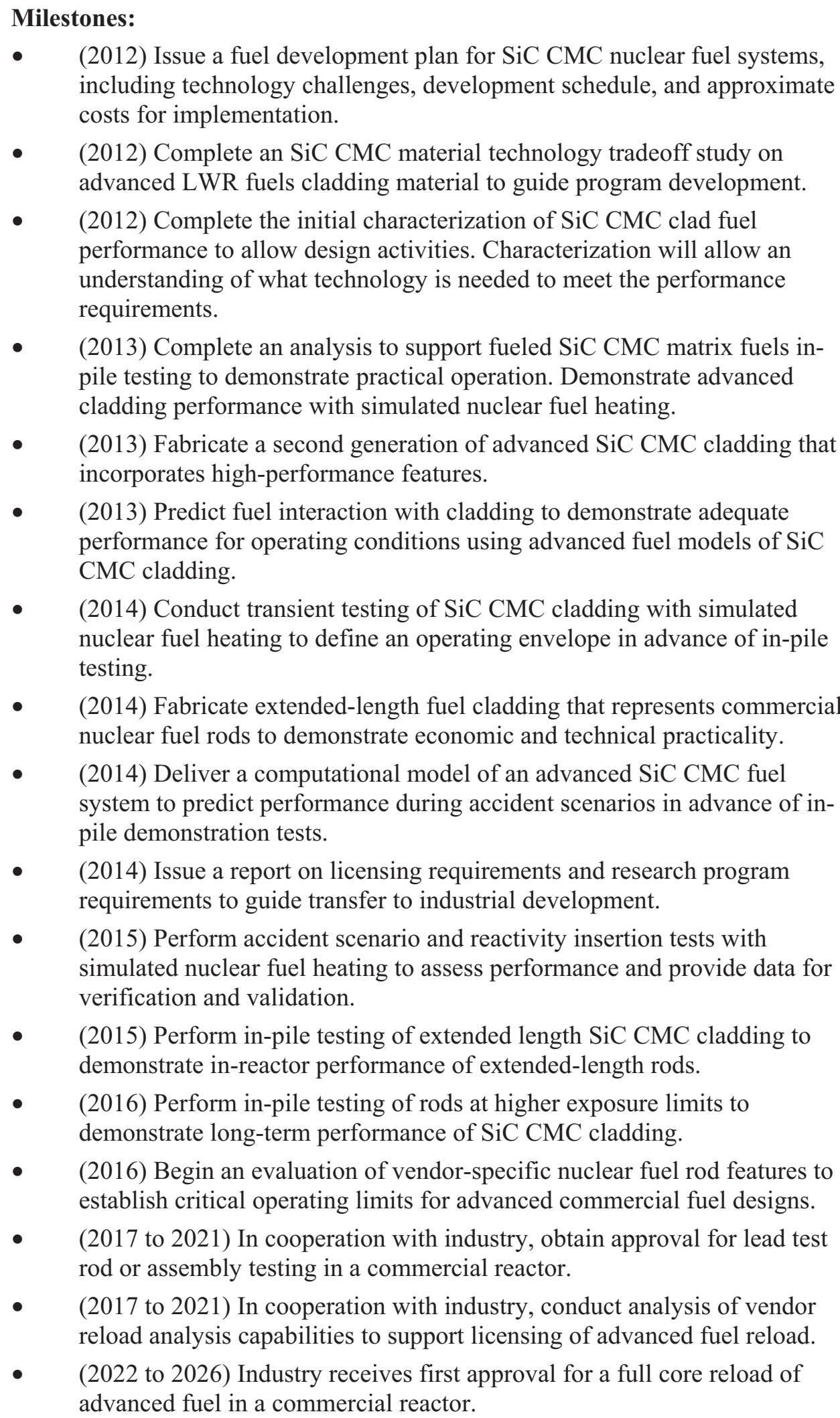 \\
\hline
\end{tabular}




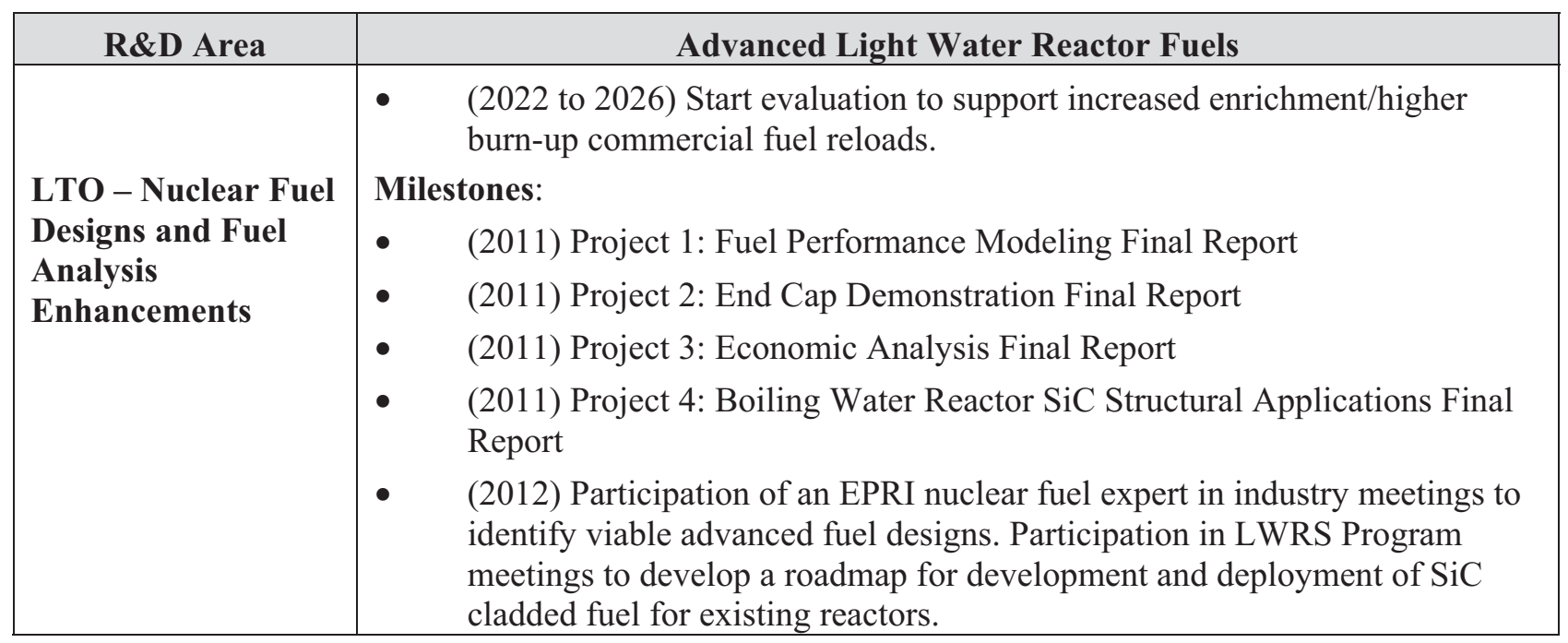

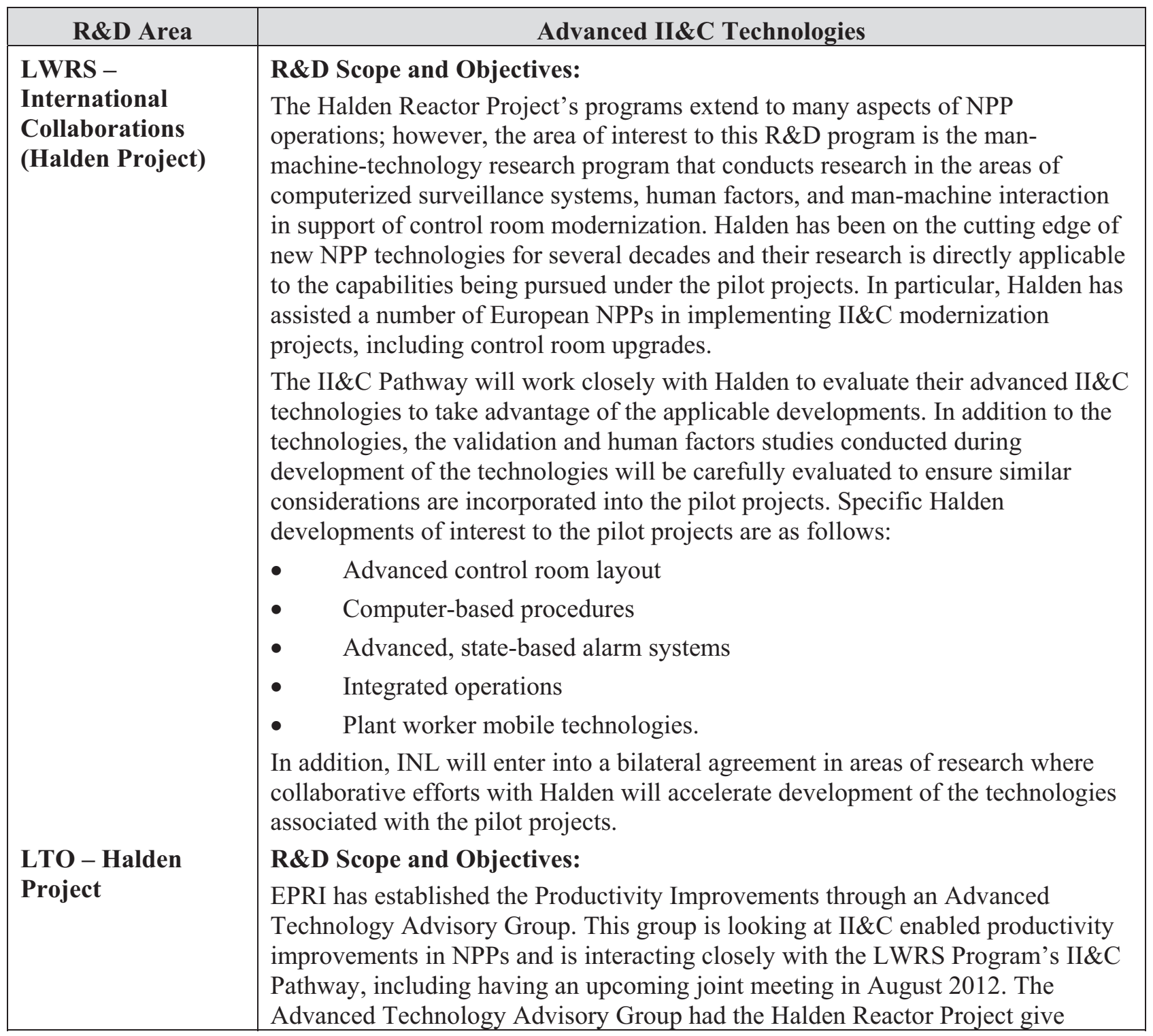




\begin{tabular}{|l|l|}
\hline \multicolumn{1}{|c|}{ R\&D Area } & \multicolumn{1}{c|}{ Advanced II\&C Technologies } \\
\hline & $\begin{array}{l}\text { presentations in the June 2010 meeting and will have them give more } \\
\text { presentations in the April 2012 meeting. The intent is to identify opportunities to } \\
\text { support productivity improvements in NPPs, taking advantage of activities in } \\
\text { Halden's Man-Machine-Technology Program. EPRI, as an associated member of } \\
\text { the Halden Reactor Project, is providing input to Halden on their research } \\
\text { activities in the Man-Machine-Technology Program. }\end{array}$ \\
\hline $\begin{array}{l}\text { LWRS - } \\
\text { International } \\
\text { Collaborations } \\
\text { (Halden Project) } \\
\text { LTO- Halden } \\
\text { Project }\end{array}$ & $\begin{array}{l}\text { Milestones: } \\
\text { (2011) Agreement between Halden and INL signed. }\end{array}$ \\
\hline
\end{tabular}

\begin{tabular}{|c|c|}
\hline R\&D Area & RISMC \\
\hline $\begin{array}{l}\text { LTO - Enhanced } \\
\text { Risk Assessment } \\
\text { and Management } \\
\text { Capability }\end{array}$ & $\begin{array}{l}\text { R\&D Scope and Objectives: } \\
\text { To achieve successful long-term operations of the current fleet of operating NPPs, } \\
\text { it will be imperative that high levels of safety and economic performance are } \\
\text { maintained. Therefore, operating NPPs will have a continuing need to undergo } \\
\text { design and operational changes, as well as manage aging degradation while } \\
\text { simultaneously preventing the occurrence of safety significant events and } \\
\text { analytically demonstrating improved nuclear safety. This portion of the EPRI } \\
\text { LTO Program addresses two specific issues that are imperative to achieving these } \\
\text { objectives: } \\
\text { (1) First, as the current fleet of operational NPPs ages, it is anticipated that new } \\
\text { challenges to NPP safety will emerge. These challenges could be due to any } \\
\text { number of causes such as a change in regulatory policy or the occurrence of an } \\
\text { event at one or more operational plants. } \\
\text { (2) Second, as new technologies and capabilities become available, it will be } \\
\text { desirable to take advantage of these opportunities to enhance plant technical and } \\
\text { economic performance. Examples of such enhancements could include } \\
\text { performing extended power uprates or implementation of new technologies or } \\
\text { materials. } \\
\text { In each situation, a comprehensive and integrated assessment of the impact on } \\
\text { nuclear safety will be required to support effective and efficient decision making. } \\
\text { This research project will develop and validate enhanced risk assessment and } \\
\text { management capabilities and tools. A critical element of this research effort will } \\
\text { be to integrate the results obtained from the EPRI PHOENIX software } \\
\text { development effort, which is being conducted to develop an advanced } \\
\text { probabilistic risk assessment and configuration risk management integrated tool } \\
\text { suite. This research effort will support development of PHOENIX by integrating } \\
\text { risk management analytical capabilities that are necessary for NPP long-term } \\
\text { operations (e.g., RISMC) and providing for the capability for the Phoenix } \\
\text { software to link to the RELAP-7 software to permit its uses as a risk simulation } \\
\text { tool. This project also provides significant interface and coordination of research } \\
\text { efforts being conducted in safety analysis code development and safety margin } \\
\text { analyses being performed by INL as part of the LWRS Program. }\end{array}$ \\
\hline
\end{tabular}




\begin{tabular}{|l|l|}
\hline R\&D Area & RISMC \\
\hline $\begin{array}{l}\text { LTO - Enhanced } \\
\text { Risk Assessment } \\
\text { and Management } \\
\text { Capability }\end{array}$ & $\begin{array}{l}\text { Milestones: } \\
\text { In previous years, this LTO research effort has supported the Phase 1 and Phase 2 } \\
\text { portions of the PHOENIX research effort. A key milestone provided by this } \\
\text { research was development of the PHOENIX functional requirements document } \\
\text { and roadmap (EPRI Report 1019207). During 2012 and 2013, the support of } \\
\text { PHOENIX development, testing, and initial deployment will continue. The } \\
\text { following activities are planned: } \\
\text { (December 2012) Update of PHOENIX software development plan to } \\
\text { incorporate LTO Program and LWRS Program requirements. This will } \\
\text { include prioritization of LTO-related applications for inclusion into } \\
\text { PHOENIX and the integration of these modules into the PHOENIX } \\
\text { development plan and roadmap. } \\
\text { (Starting in 2013) Conduct a PHOENIX LTO pilot application and report } \\
\text { results during 2014. }\end{array}$ \\
\hline
\end{tabular}

\section{LIGHT WATER REACTOR SUSTAINABILITY/LONG-TERM OPERATIONS COLLABORATIVE RESEARCH AND DEVELOPMENT ACTIVITIES}

\begin{tabular}{|c|c|}
\hline R\&D Area & $\begin{array}{c}\text { Materials Aging and Degradation (LWRS)/Understanding, Prediction, and } \\
\text { Mitigation of Primary System Aging Degradation (LTO) }\end{array}$ \\
\hline $\begin{array}{l}\text { LWRS - Expanded } \\
\text { Proactive Materials } \\
\text { Degradation Analysis }\end{array}$ & $\begin{array}{l}\text { R\&D Scope and Objectives: } \\
\text { A proactive materials degradation analysis is a comprehensive evaluation of } \\
\text { degradation modes for LWR applications, based on knowledge level, severity of } \\
\text { degradation, and likelihood of occurrence. The degradation of core internals and } \\
\text { primary piping for nuclear reactor applications was evaluated in considerable } \\
\text { detail in the original NRC-led proactive materials degradation analysis } \\
\text { (NUREG/CR-6923). This assessment has proven to be a very valuable resource } \\
\text { in component aging management and regulation. Consequently, an expanded } \\
\text { proactive materials degradation analysis-type activity is being performed to } \\
\text { address extended service and include components beyond the primary piping and } \\
\text { core internals. The proactive materials degradation analysis approach to extended } \\
\text { service has the following key benefits: } \\
\text { - } \quad \text { Captures current knowledge base } \\
\text { - Identifies gaps in knowledge for a component or material system that must } \\
\text { be resolved } \\
\text { May help identify new forms of degradation } \\
\text { - Identifies and prioritizes research needs and directions } \\
\text { Builds collaborations between industry, regulatory, and government } \\
\text { - Is in a format familiar to industry. } \\
\text { This Expanded Proactive Materials Degradation Analysis is being conducted in a } \\
\text { cooperative partnership between NRC and DOE's LWRS Program. }\end{array}$ \\
\hline
\end{tabular}




\begin{tabular}{|c|c|}
\hline R\&D Area & $\begin{array}{c}\text { Materials Aging and Degradation (LWRS)/Understanding, Prediction, and } \\
\text { Mitigation of Primary System Aging Degradation (LTO) }\end{array}$ \\
\hline $\begin{array}{l}\text { LTO - Extension of } \\
\text { MDM and IMTs to } \\
\text { Include Failure } \\
\text { Mechanisms to } \\
80 \text { Years }\end{array}$ & $\begin{array}{l}\text { R\&D Scope and Objectives: } \\
\text { The EPRI MDM, Pressurized Water Reactor IMT, and Boiling Water Reactor } \\
\text { IMT are three key reference documents that are part of the industry's materials } \\
\text { initiative guided by NEI 03-08. The MDM and IMTs identify knowledge gaps } \\
\text { based on likely degradation mechanisms and aging issues through an expert } \\
\text { elicitation process. The MDM and IMTs also assess the state of industry } \\
\text { knowledge worldwide, survey the laboratory data and field experience data, and } \\
\text { prioritize the gaps for industry to resolve in the most effective way. } \\
\text { MDM results are used as direct inputs into the Pressurized Water Reactor IMT } \\
\text { and Boiling Water Reactor IMT. Degradation mechanisms identified in MDM } \\
\text { are used as primary input for the set of degradation mechanisms considered by } \\
\text { the IMT process. The MDM was first published in } 2004 \text { (Revision 0), and } \\
\text { revised in 2007 (Revision 1). Sequentially, two IMTs were first published in } \\
2005 \text { (Revision 0) and then revised in } 2008 \text { (Revision } 1 \text { ). The Revision } 0 \text { and } \\
\text { Revision } 1 \text { of MDM and the IMTs only addressed issues related to the current } \\
\text { license period (40 years of operation) and the license renewal period (from } 40 \text { to } \\
60 \text { years of operation). The goal of the LTO Program is to extend MDM and the } \\
\text { IMTs to } 80 \text { years of operation. The objectives of ongoing revision (Revision } 2 \text { ) } \\
\text { of MDM and the IMTs are as follows: } \\
\text { - } \\
\text { Identify applicable degradation mechanisms and assess the extent to which } \\
\text { applicable degradation mechanisms are understood } \\
\text { Evaluate the worldwide state of industry knowledge associated with } \\
\text { mitigation of degradation mechanisms } \\
\text { Address any concerns related to regulatory and licensing renewal } \\
\text { considerations. } \\
\text { The MDM and IMTs are living documents and they require updates and } \\
\text { revisions periodically to reflect the knowledge gained and the evolving } \\
\text { challenges. }\end{array}$ \\
\hline $\begin{array}{l}\text { LWRS - Expanded } \\
\text { Proactive Materials } \\
\text { Degradation Analysis } \\
\text { LTO - MDM/IMTs }\end{array}$ & $\begin{array}{l}\text { Milestones: } \\
\text { - (2012) Complete the Expanded Proactive Materials Degradation Analysis } \\
\text { gap analysis of the materials degradation modes. } \\
\text { Milestones: } \\
\text { - }(2012,2015 \text {, and 2018) MDM revision every } 3 \text { years. } \\
\text { - }(2013,2016 \text {, and 2019) IMTs revision every } 3 \text { years. }\end{array}$ \\
\hline \multicolumn{2}{|l|}{ Reactor Metals } \\
\hline $\begin{array}{l}\text { LWRS - } \\
\text { Mechanisms of } \\
\text { IASCC }\end{array}$ & $\begin{array}{l}\text { R\&D Scope and Objectives: } \\
\text { Mechanisms of IASCC in stainless steels provide understanding of the role of } \\
\text { composition, history, and the environment on IASCC and model capability. This } \\
\text { will be accomplished through a partnership with EPRI by performing tests in } \\
\text { simulated water environments (both crack growth and tensile tests) in addition to } \\
\text { complementary post-irradiation examination of irradiation effects on a series of } \\
\text { service materials and model alloys. Combined, these single variable experiments } \\
\text { will provide mechanistic understanding that can be used to identify key } \\
\text { operational variables to mitigate or control IASCC, to optimize inspection and }\end{array}$ \\
\hline
\end{tabular}




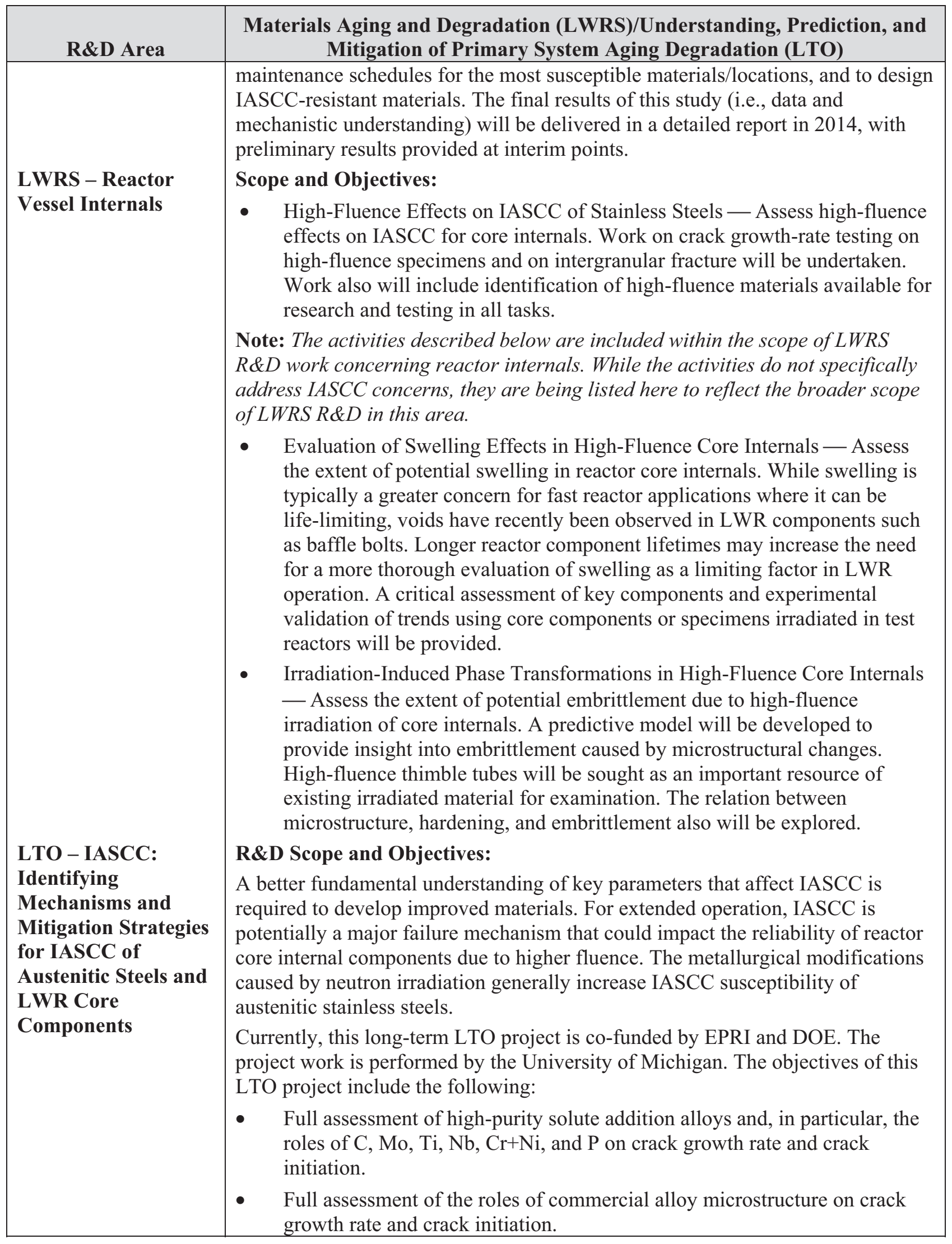




\begin{tabular}{|c|c|}
\hline R\&D Area & $\begin{array}{c}\text { Materials Aging and Degradation (LWRS)/Understanding, Prediction, and } \\
\text { Mitigation of Primary System Aging Degradation (LTO) }\end{array}$ \\
\hline & $\begin{array}{l}\text { Linkage between irradiated microstructure and crack growth rate or crack } \\
\text { initiation for solute addition and commercial alloys, as well as effects of } \\
\text { cold work and dose. } \\
\text { Relation between IASCC cracking susceptibility and neutron irradiated } \\
\text { alloys. } \\
\text { Determination of the predictive capability of crack initiation due to proton } \\
\text { irradiation by assessment against crack initiation due to neutron irradiation. } \\
\text { Role of localized deformation on the IASCC susceptibility in neutron } \\
\text { irradiated materials. } \\
\text { In addition to testing the neutron-irradiated stainless steels, the similar stainless } \\
\text { steels irradiated to the similar fluence by proton irradiation will be tested by } \\
\text { constant extension-rate tensile tests. The cracking susceptibilities associated with } \\
\text { neutron irradiation and with proton irradiation will be cross compared. The role } \\
\text { of localized deformation on IASCC susceptibility will be investigated. } \\
\text { This LTO project is a 5-year effort that started in 2009. The scope of this LTO } \\
\text { project can be summarized as investigating the following: } \\
\text { - } \quad \text { Role of solutes in crack initiation } \\
\text { - } \quad \text { Role of solutes in crack propagation } \\
\text { - } \quad \text { Role of starting microstructure in crack initiation } \\
\text { - } \quad \text { Role of starting microstructure in crack propagation } \\
\text { - } \quad \text { Effectiveness of proton irradiation in forecasting relative crack growth rate } \\
\text { behavior } \\
\text { - Comparison of crack initiation following proton and neutron irradiation } \\
\text { - } \quad \text { Comparison of crack initiation and crack growth in neutron-irradiated } \\
\text { - } \quad \text { Structure-property relationship for neutron irradiated alloys } \\
\text { on development of radiation-resistant materials for LWR applications. EPRI and } \\
\text { DOE will jointly prepare a comprehensive report on the state of current } \\
\text { knowledge of radiation-induced degradation in LWRs and prepare a roadmap to } \\
\text { develop and qualify more radiation-resistant materials. The resulting roadmap } \\
\text { will be used to formulate a long-range R\&D plan to develop improved materials } \\
\text { for current and new NPPs. } \\
\text { initiation. }\end{array}$ \\
\hline $\begin{array}{l}\text { LWRS - } \\
\text { Mechanisms of } \\
\text { IASCC } \\
\text { LWRS - Reactor } \\
\text { Vessel Internals }\end{array}$ & $\begin{array}{l}\text { Milestones: } \\
\text { - Deliver mechanistic understanding for key materials and degradation } \\
\text { modes, including the following: } \\
\text { - } \quad \text { (2014) Issue a final report on IASCC (data and mechanistic } \\
\text { understanding). } \\
\text { (2013) Prepare a comprehensive report on the state of current knowledge } \\
\text { of radiation-induced degradation in LWRs and prepare a roadmap to } \\
\text { develop and qualify more radiation-resistant materials. (This effort links }\end{array}$ \\
\hline
\end{tabular}




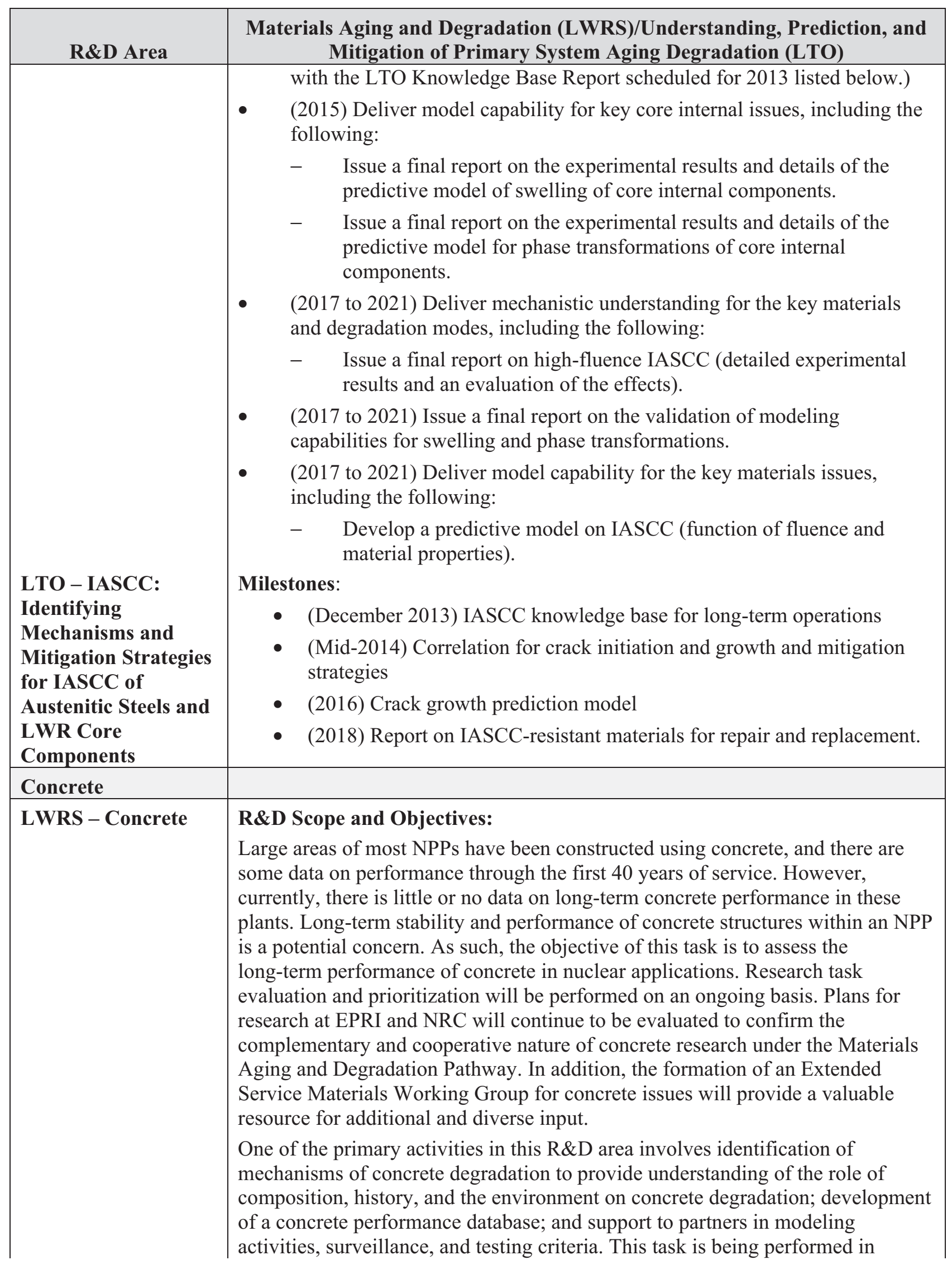




\begin{tabular}{|c|c|}
\hline R\&D Area & $\begin{array}{c}\text { Materials Aging and Degradation (LWRS)/Understanding, Prediction, and } \\
\text { Mitigation of Primary System Aging Degradation (LTO) }\end{array}$ \\
\hline $\begin{array}{l}\text { LTO - } \\
\text { Comprehensive } \\
\text { Aging Management } \\
\text { of Concrete } \\
\text { Structures }\end{array}$ & 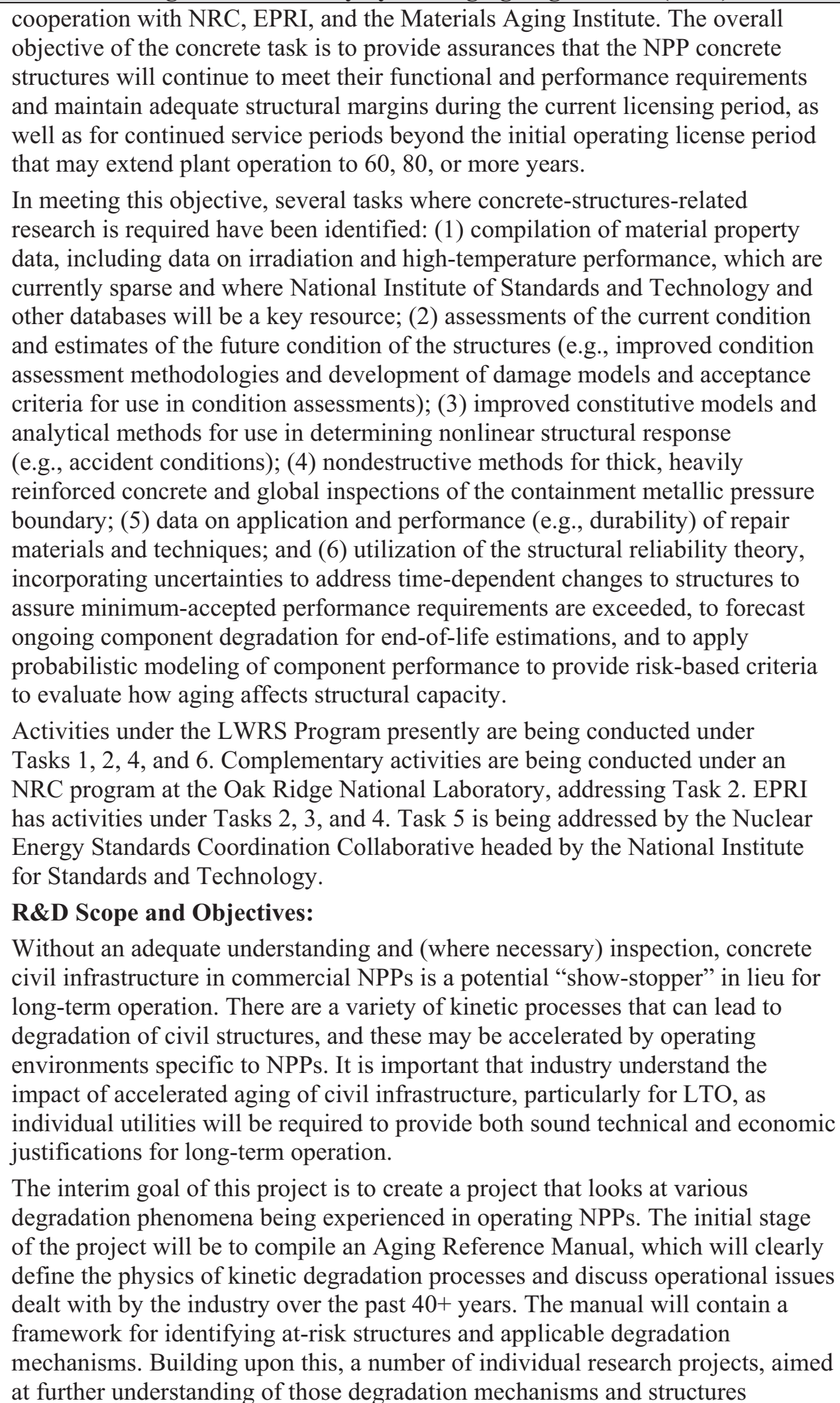 \\
\hline
\end{tabular}




\begin{tabular}{|c|c|}
\hline R\&D Area & $\begin{array}{c}\text { Materials Aging and Degradation (LWRS)/Understanding, Prediction, and } \\
\text { Mitigation of Primary System Aging Degradation (LTO) }\end{array}$ \\
\hline & $\begin{array}{l}\text { identified as "at-risk," will be commenced. The results of the individual studies } \\
\text { will be merged into an Aging Management Toolbox Platform, which will be an } \\
\text { open-ended tool for operators to assess the severity of damage and explore repair } \\
\text { or mitigation options. It is anticipated that this investigation will yield one or } \\
\text { more industry examination guidelines for concrete aging assessment. }\end{array}$ \\
\hline LWRS - Concrete & $\begin{array}{l}\text { Milestones: } \\
\text { - (2013) Complete Containment Inspection Guidelines for extended-service } \\
\text { conditions through partnership with Constellation Energy and EPRI. } \\
\text { (2016) Deliver a detailed database containing relevant and validated data } \\
\text { for extended service, high-temperature effects, and irradiation effects on } \\
\text { concrete performance. }\end{array}$ \\
\hline \multirow[t]{3}{*}{$\begin{array}{l}\text { LTO - } \\
\text { Comprehensive } \\
\text { Aging Management } \\
\text { of Concrete } \\
\text { Structures }\end{array}$} & $\begin{array}{l}\text { Milestones: } \\
\text { - } \\
\text { (2011) Complete and publish a Concrete Structures Aging Reference } \\
\text { Manual } \\
\text { (2011) Issue report on leaking spent fuel pools (structural significance of } \\
\text { boric acid degradation of reinforced concrete) }\end{array}$ \\
\hline & $\begin{array}{l}\text { (2012) Issue reports on chloride attack case study (Palo Verde Nuclear } \\
\text { Generating Station) }\end{array}$ \\
\hline & $\begin{array}{l}\text { - (2012 and 2013) Containment aging pilot plant investigation Outage } 2011 \\
\text { and Outage 2012 reports (results of destructive examination/NDE at Ginna } \\
\text { and Nine Mile Point); industry guideline(s) for examination of structures } \\
\text { for concrete aging } \\
\text { (2016) Report on radiation damage effects on concrete. }\end{array}$ \\
\hline \multicolumn{2}{|l|}{ Mitigation Strategies } \\
\hline \multirow{3}{*}{$\begin{array}{l}\text { LWRS - Weld } \\
\text { Repair Techniques }\end{array}$} & R\&D Scope and Objectives: \\
\hline & $\begin{array}{l}\text { Weld repair provides understanding and modeling of helium effects under } \\
\text { welding, validation of residual stress models currently under development, and } \\
\text { deployment of advanced repair welding techniques. This task for developing and } \\
\text { demonstrating advanced welding technology for repair applications is being } \\
\text { performed collaboratively with EPRI. Research includes mechanistic } \\
\text { understanding of helium effects in weldments. This modeling task is supported } \\
\text { by characterization of model alloys before and after irradiation and welding. This } \\
\text { model can be used by stakeholders to further improve best practices for repair } \\
\text { welding for both existing technology and advanced technology. }\end{array}$ \\
\hline & $\begin{array}{l}\text { In addition, this task will provide validation of residual stress models under } \\
\text { development using advanced characterization techniques (such as neutron } \\
\text { scattering). Residual stress models also will improve best practices for } \\
\text { weldments of NPPs today and under extended service conditions. These tools } \\
\text { could be expanded to include other industry practices (such as peening). Finally, } \\
\text { advanced welding techniques (such as friction-stir welding, laser welding, and } \\
\text { hybrid techniques) will be developed and demonstrated on relevant materials } \\
\text { (model and service alloys). Characterization of the weldments and qualification } \\
\text { testing will be an essential step. }\end{array}$ \\
\hline
\end{tabular}




\begin{tabular}{|c|c|}
\hline R\&D Area & $\begin{array}{c}\text { Materials Aging and Degradation (LWRS)/Understanding, Prediction, and } \\
\text { Mitigation of Primary System Aging Degradation (LTO) }\end{array}$ \\
\hline $\begin{array}{l}\text { LTO - Advanced } \\
\text { Welding Methods for } \\
\text { Irradiated Materials }\end{array}$ & 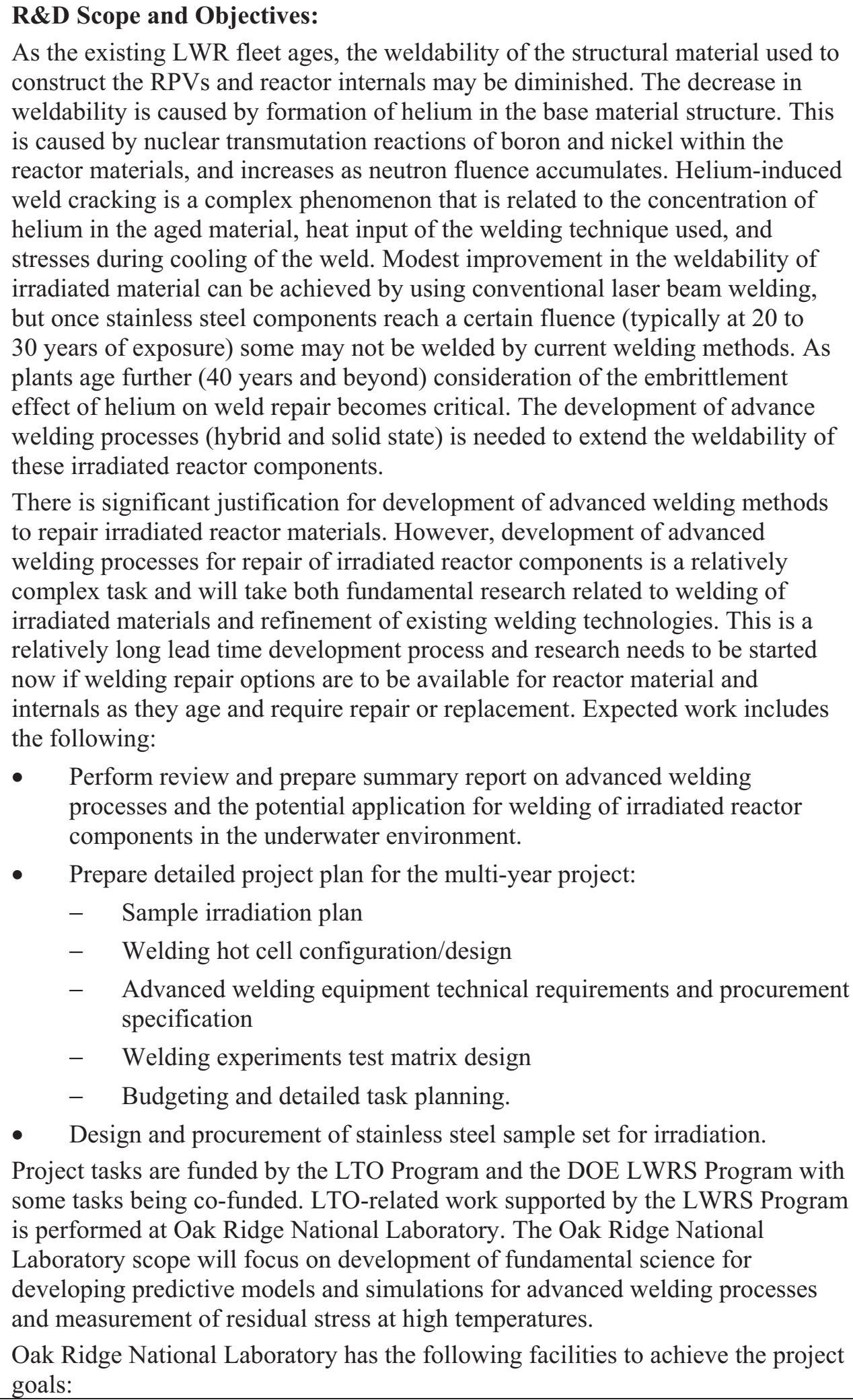 \\
\hline
\end{tabular}




\begin{tabular}{|c|c|}
\hline R\&D Area & $\begin{array}{c}\text { Materials Aging and Degradation (LWRS)/Understanding, Prediction, and } \\
\text { Mitigation of Primary System Aging Degradation (LTO) }\end{array}$ \\
\hline & $\begin{array}{l}\text { - High-Flux Isotope Reactor - Irradiation of the sample set will occur at this } \\
\text { facility, as well as potential measurement of residual stresses at high } \\
\text { temperature. } \\
\text { Material Process Hot Cell - Welding of irradiated material requires } \\
\text { facilities that can remotely handle radioactive materials. } \\
\text { Advanced Microstructure Characterization Laboratory - Examination of } \\
\text { radioactive material at the sub-grain level is a unique capability of Oak } \\
\text { Ridge National Laboratory. }\end{array}$ \\
\hline $\begin{array}{l}\text { LWRS - Weld } \\
\text { Repair Techniques }\end{array}$ & $\begin{array}{l}\text { Milestones: } \\
\text { - (2016) Issue a final report on the technology transfer of advanced weld } \\
\text { repair techniques (mechanistic studies, model development, supporting } \\
\text { data, and development). }\end{array}$ \\
\hline $\begin{array}{l}\text { LTO - Advanced } \\
\text { Welding Methods for } \\
\text { Irradiated Materials }\end{array}$ & $\begin{array}{l}\text { Milestones: } \\
\text { - (2012) Project status report for } 2010 \text { and } 2011 \text { and detail project plan for the } \\
\text { remainder of project (EPRI Technical Update Report) } \\
\text { - (2013) Hybrid and Solid State Welding: Methods and Technical Basis } \\
\text { Report } \\
\text { - (2014) Hybrid and Solid State Welding: Guidelines and Validation } \\
\text { - (2015) Final Report. }\end{array}$ \\
\hline
\end{tabular}

\begin{tabular}{|c|c|}
\hline R\&D Area & Advanced II\&C Technologies \\
\hline $\begin{array}{l}\text { LWRS - New } \\
\text { Instrumentation and } \\
\text { Control and Human } \\
\text { System Interfaces } \\
\text { and Capabilities } \\
\text { (including Advanced } \\
\text { II\&C Pilot Projects) }\end{array}$ & $\begin{array}{l}\text { R\&D Scope and Objectives: } \\
\text { R\&D activities are being proposed to develop needed capabilities through digital } \\
\text { technologies to support long-term NPP operations and management. The } \\
\text { supporting technologies will enable the large integrated changes that industry } \\
\text { cannot achieve without direct R\&D support. This includes comprehensive } \\
\text { programs that achieve the following: } \\
\text { - Support creation of new technologies that can be deployed to address the } \\
\text { sustainability of today's II\&C systems technologies } \\
\text { Improve understanding of, confidence in, and facilitate transition to these } \\
\text { new technologies } \\
\text { - Support development of the technical basis needed to achieve technology } \\
\text { deployments } \\
\text { Create or renew infrastructure needed for research, education, and testing } \\
\text { This research program will address the aging and long-term reliability issues of } \\
\text { the legacy II\&C systems used in the current LWR fleet by demonstrating new } \\
\text { technologies and operational concepts in actual NPP settings. This approach } \\
\text { drives the following two important outcomes: } \\
\text { - Reduces the technical, financial, and regulatory risk of upgrading the aging } \\
\text { II\&C systems to support extended plant life beyond } 60 \text { years. } \\
\text { Provides the technological foundation for a transformed NPP operating } \\
\text { model that improves plant performance and addresses the challenges of the } \\
\text { future business environment. }\end{array}$ \\
\hline
\end{tabular}




\begin{tabular}{|c|c|}
\hline R\&D Area & Advanced II\&C Technologies \\
\hline $\begin{array}{l}\text { LTO - Requirements } \\
\text { Database for } \\
\text { Advanced I\&C, } \\
\text { Human System } \\
\text { Interface, and } \\
\text { Information } \\
\text { Technology }\end{array}$ & 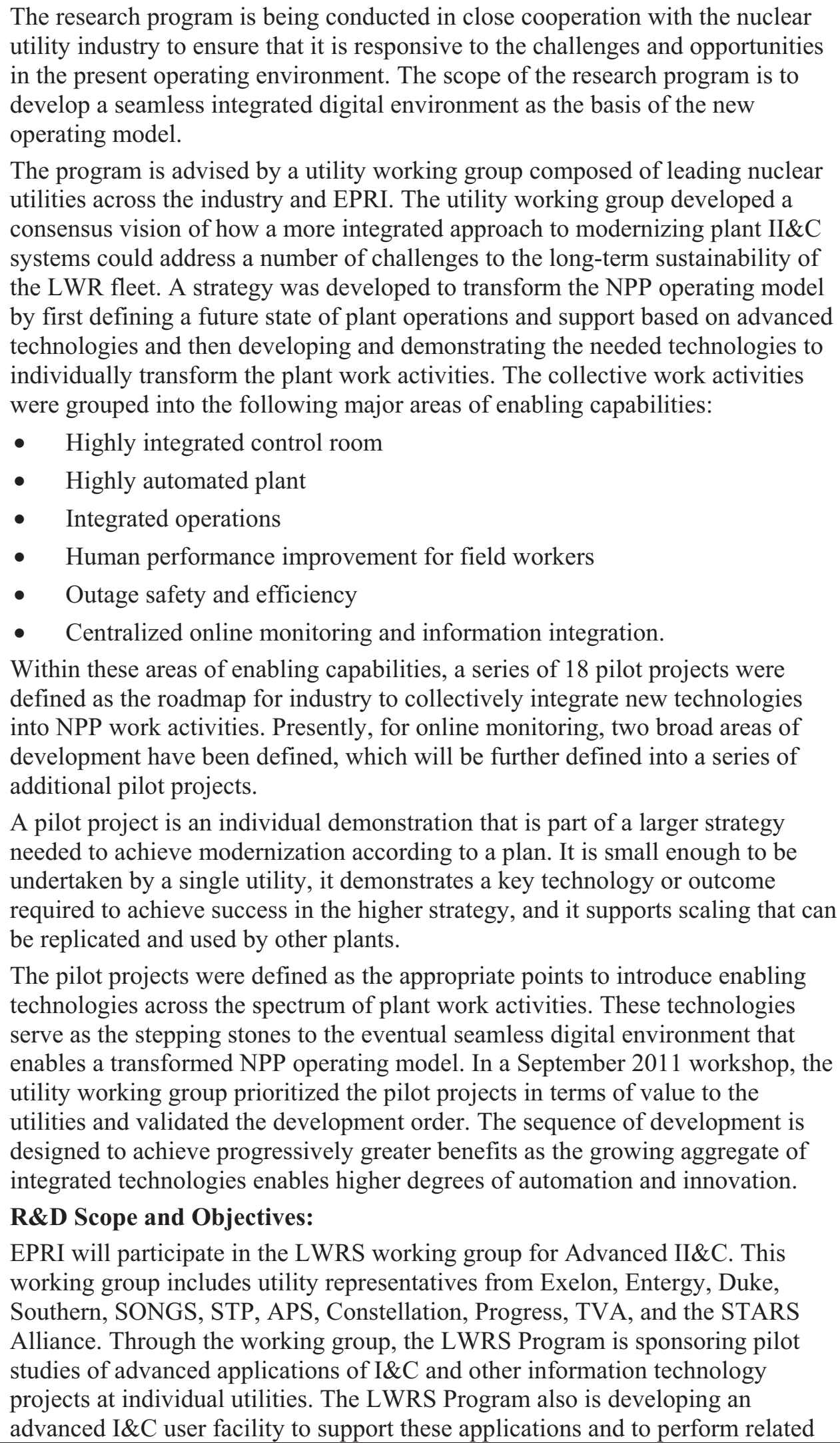 \\
\hline
\end{tabular}




\begin{tabular}{|c|c|}
\hline R\&D Area & Advanced II\&C Technologies \\
\hline & $\begin{array}{l}\text { R\&D at INL. EPRI will participate in these activities on behalf of the LTO } \\
\text { project membership. EPRI will interact with the working group on the LTO } \\
\text { requirements database activities. EPRI is making relevant EPRI technical reports } \\
\text { available to INL for work in the LWRS Advanced II\&C area. }\end{array}$ \\
\hline $\begin{array}{l}\text { LWRS - New } \\
\text { Instrumentation and } \\
\text { Control and Human } \\
\text { System Interfaces } \\
\text { and Capabilities } \\
\text { (including advanced } \\
\text { II\&C pilot projects) }\end{array}$ & 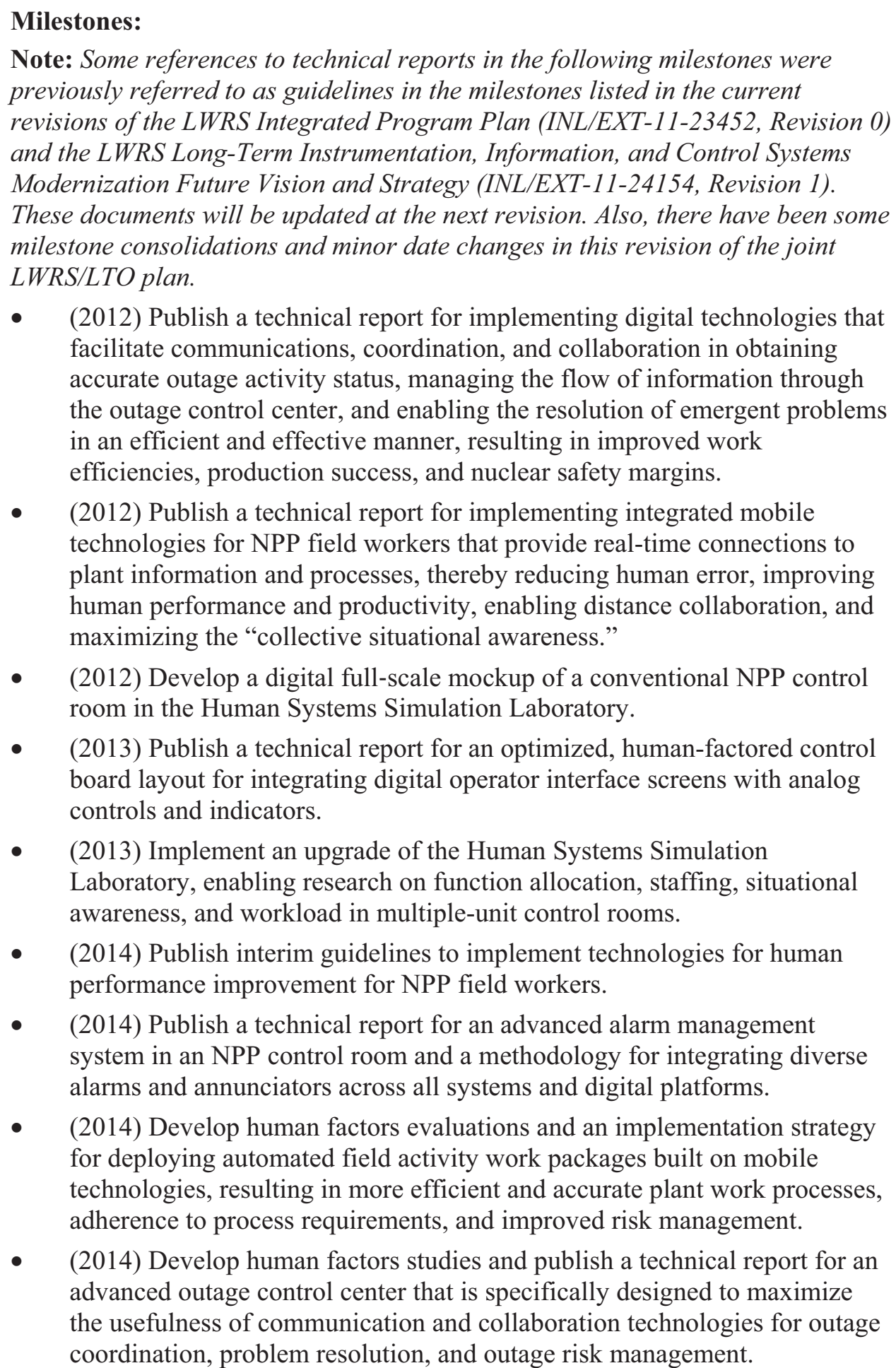 \\
\hline
\end{tabular}




\begin{tabular}{|c|c|}
\hline R\&D Area & Advanced II\&C Technologies \\
\hline & 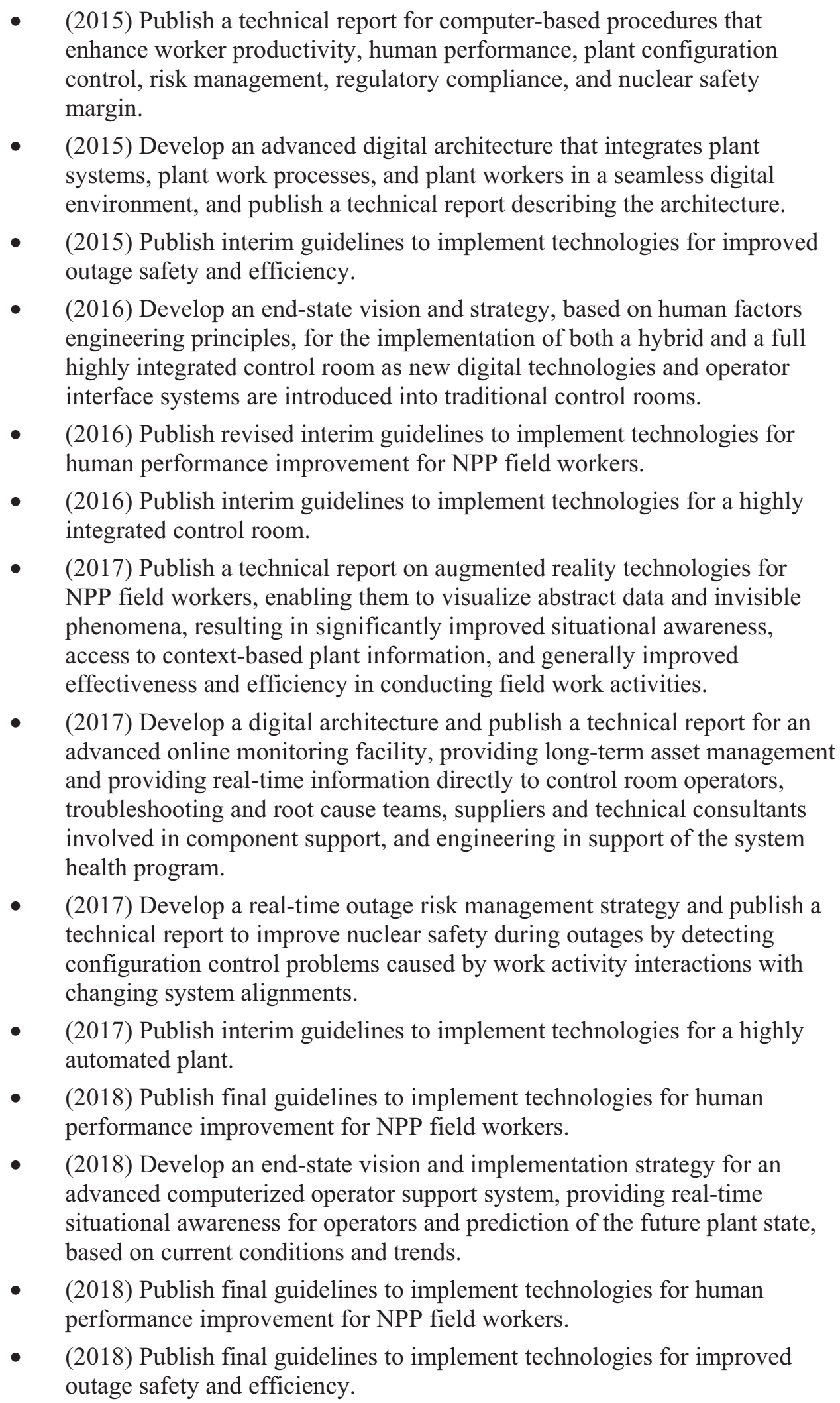 \\
\hline
\end{tabular}




\begin{tabular}{|c|c|}
\hline R\&D Area & Advanced II\&C Technologies \\
\hline $\begin{array}{l}\text { LTO - Requirements } \\
\text { Database for } \\
\text { Advanced I\&C, } \\
\text { Human System } \\
\text { Interface, and } \\
\text { Information } \\
\text { Technology }\end{array}$ & 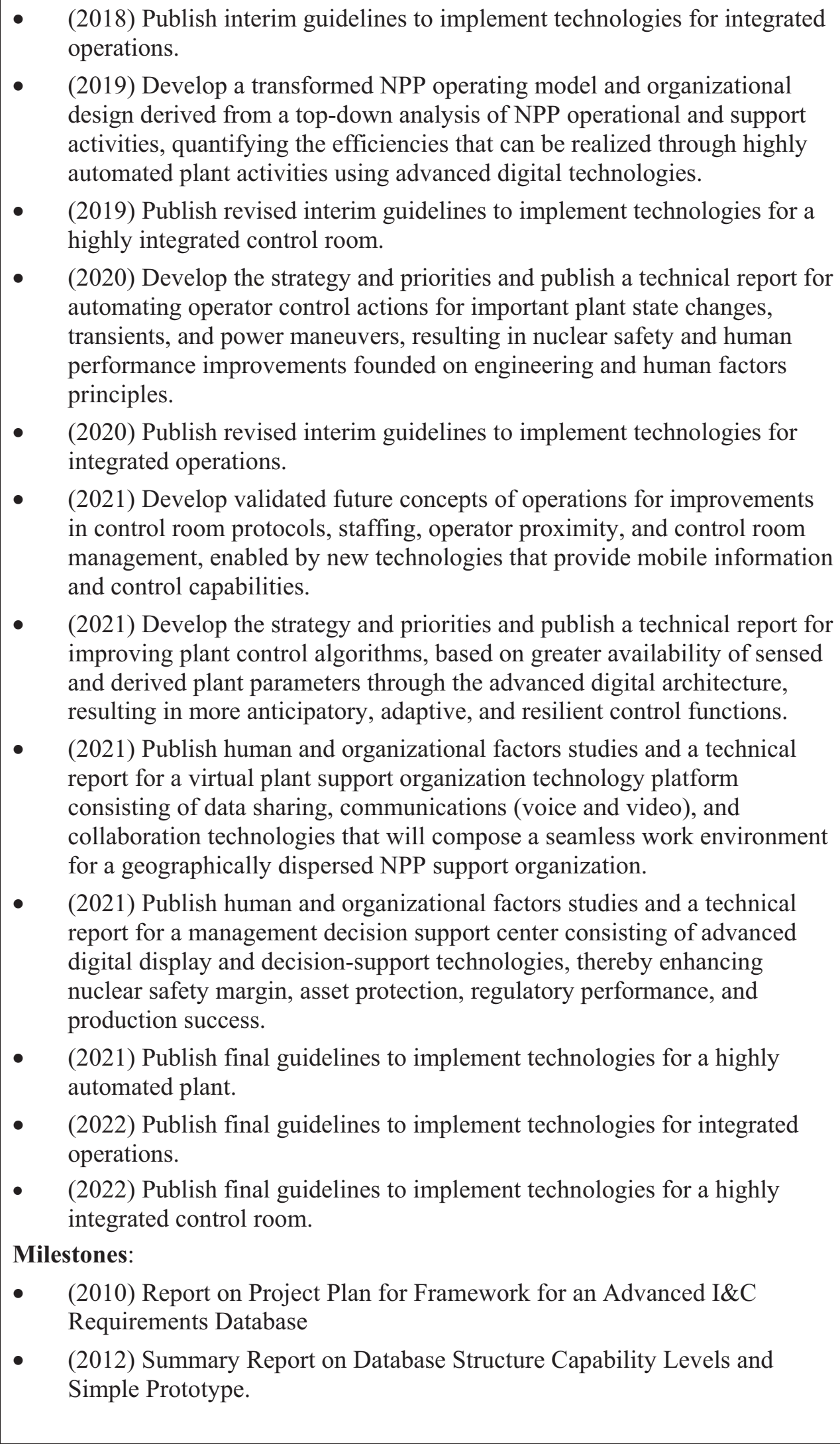 \\
\hline
\end{tabular}




\begin{tabular}{|c|c|}
\hline R\&D Area & Advanced II\&C Technologies \\
\hline & $\begin{array}{l}\text { The following deliverables will be jointly developed by LWRS and LTO and are } \\
\text { listed identically as milestones for each program: } \\
\text { - } \\
\text { - } 2014 \text { ) Publish interim guidelines to implement technologies for Human } \\
\text { Performance Improvement for NPP Field Workers. } \\
\text { (2015) Publish interim guidelines to implement technologies for improved } \\
\text { outage safety and efficiency. } \\
\text { (2016) Publish revised interim guidelines to implement technologies for } \\
\text { human Performance Improvement for NPP field workers. } \\
\text { - (2016) Publish interim guidelines to implement technologies for a highly } \\
\text { integrated control room. } \\
\text { (2017) Publish interim guidelines to implement technologies for a highly } \\
\text { automated plant. } \\
\text { (2018) Publish final guidelines to implement technologies for human } \\
\text { performance improvement for NPP field workers. } \\
\text { (2018) Publish final guidelines to implement technologies for improved } \\
\text { outage safety and efficiency. } \\
\text { (2018) Publish interim guidelines to implement technologies for integrated } \\
\text { operations. } \\
\text { (2019) Publish revised interim guidelines to implement technologies for a } \\
\text { highly integrated control room. } \\
\text { (2020) Publish revised interim guidelines to implement technologies for } \\
\text { integrated operations. } \\
\text { (2021) Publish final guidelines to implement technologies for a highly } \\
\text { automated plant. } \\
\text { (2022) Publish final guidelines to implement technologies for integrated } \\
\text { operations. } \\
\text { (2022) Publish final guidelines to implement technologies for a highly } \\
\text { integrated control room. }\end{array}$ \\
\hline $\begin{array}{l}\text { LWRS - Centralized } \\
\text { Online Monitoring } \\
\text { and Information } \\
\text { Integration }\end{array}$ & $\begin{array}{l}\text { R\&D Scope and Objectives: } \\
\text { As NPP systems are operated during periods longer than originally anticipated, } \\
\text { the need arises for more and better types of monitoring of material and system } \\
\text { performance. This includes the need to move from periodic, manual assessments } \\
\text { and surveillances of physical systems to online condition monitoring. This } \\
\text { represents an important transformational step in the management of NPPs. It } \\
\text { enables real-time assessment and monitoring of physical systems and better } \\
\text { management of active components based on their performance. It also provides } \\
\text { the ability to gather substantially more data through automated means and to } \\
\text { analyze and trend performance using new methods to make more informed } \\
\text { decisions about NPP management and safety management. Of particular } \\
\text { importance will be the capability to determine the "remaining useful life" of a } \\
\text { component to justify its continued operation over an extended plant life. } \\
\text { Working closely with the Materials Aging and Degradation Pathway and EPRI, } \\
\text { this pathway will develop technologies to complement sensor development and } \\
\text { monitoring of materials to assess the performance of SSC materials during } \\
\text { long-term operation for purposes of decision making and asset management. This }\end{array}$ \\
\hline
\end{tabular}




\begin{tabular}{|c|c|}
\hline R\&D Area & Advanced II\&C Technologies \\
\hline $\begin{array}{l}\text { LTO - Centralized } \\
\text { Online Monitoring }\end{array}$ & 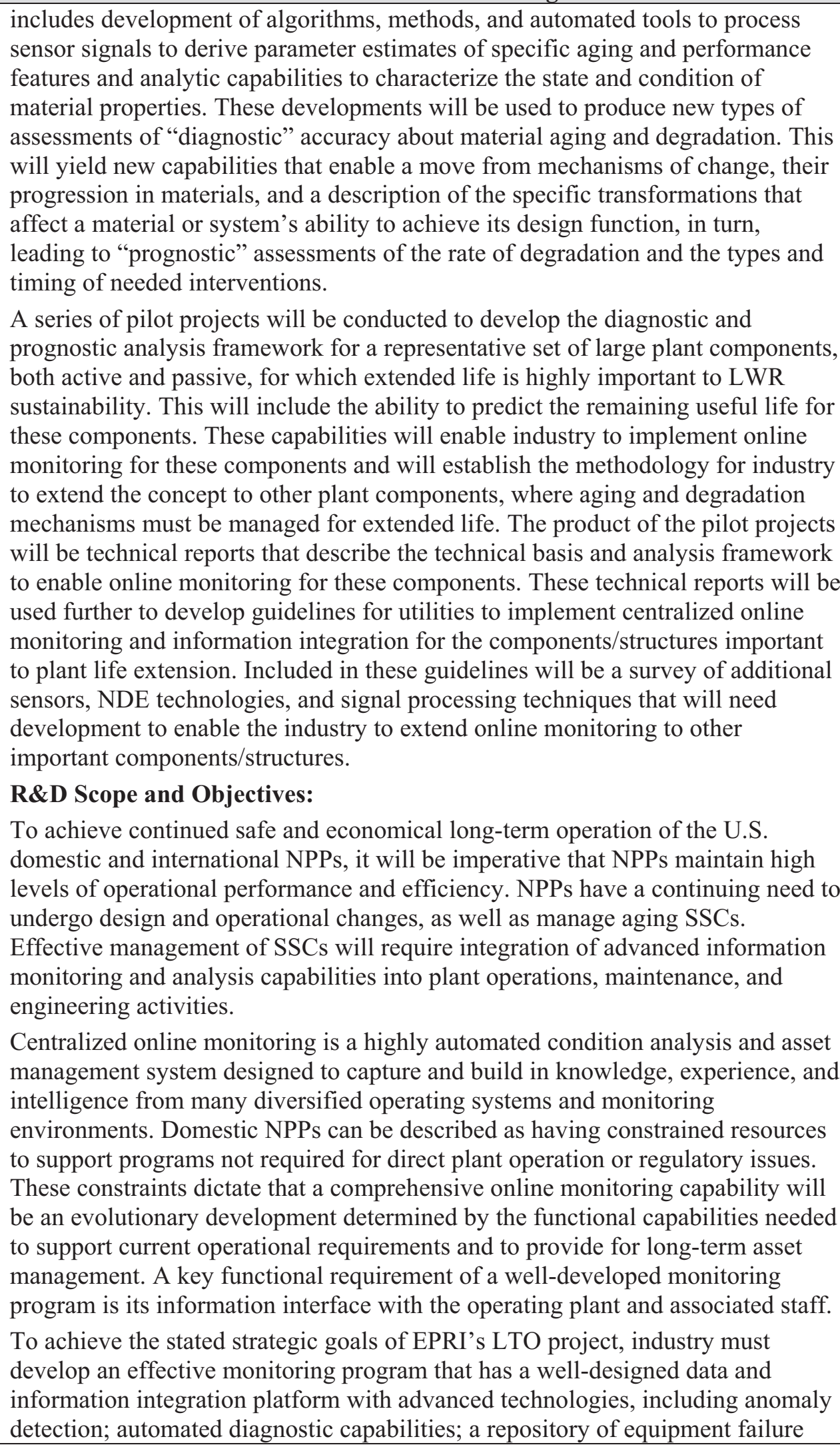 \\
\hline
\end{tabular}




\begin{tabular}{|c|c|}
\hline R\&D Area & Advanced II\&C Technologies \\
\hline & $\begin{array}{l}\text { signatures captured from industry events; and, ultimately, prognostics-remaining } \\
\text { useful life capabilities designed to evaluate critical plant assets for optimized } \\
\text { maintenance and investment decisions to support LTO. EPRI's research will } \\
\text { build on previously developed monitoring technologies and leverage the LTO } \\
\text { resources with our strategic partners. The EPRI LTO project completed an } \\
\text { in-depth industry analysis of monitoring capabilities and identified the needed } \\
\text { analytical and programmatic capabilities (gap analysis). These results provide the } \\
\text { foundation to define project priorities, identify needed technologies, project the } \\
\text { costs and schedule, obtain required funding to execute the research, and manage } \\
\text { all the implementation phases through successful implementation. In support of } \\
\text { implementation of plant monitoring programs, EPRI has published } \\
\text { comprehensive centralized online monitoring implementation guidelines, based } \\
\text { on the current state-of-the-art diagnostics and prognostics technology developed } \\
\text { by EPRI, with guidance based on early adopter and generations experience from } \\
\text { the power industry's operational monitoring centers. } \\
\text { Development and execution of the required research must include broad and } \\
\text { frequent interfacing with all of EPRI's strategic partners, including member } \\
\text { advisors and technical specialists and their commercial support organizations. } \\
\text { Other partners include qualified vendors, universities, government laboratories, } \\
\text { and utility research programs. }\end{array}$ \\
\hline $\begin{array}{l}\text { LWRS - Centralized } \\
\text { Online Monitoring } \\
\text { and Information } \\
\text { Integration }\end{array}$ & $\begin{array}{l}\text { Milestones: } \\
\text { - (2013) Publish a technical report on measures, sensors, algorithms, and } \\
\text { methods for monitoring active aging and degradation phenomena for } \\
\text { generation step-up transformers as an important passive component, } \\
\text { including the diagnostic and prognostic analysis framework to support } \\
\text { utility implementation of online monitoring for the component type. } \\
\text { (2014) Publish a technical report on measures, sensors, algorithms, and } \\
\text { methods for monitoring active aging and degradation phenomena for a } \\
\text { large active component, including the diagnostic and prognostic analysis } \\
\text { framework to support utility implementation of online monitoring for the } \\
\text { component type. } \\
\text { (2015) Publish a technical report on measures, sensors, algorithms, and } \\
\text { methods for monitoring active aging and degradation phenomena for a } \\
\text { large passive plant component/structure, involving NDE-related online } \\
\text { monitoring technology development and including the diagnostic and } \\
\text { prognostic analysis framework to support utility implementation of online } \\
\text { monitoring for the component type. } \\
\text { (2015) Publish interim guidelines to implement technologies for centralized } \\
\text { online monitoring and information integration. } \\
\text { (2016) Publish a technical report on measures, sensors, algorithms, and } \\
\text { methods for monitoring active aging and degradation phenomena for a } \\
\text { second large active plant component, including the diagnostic and } \\
\text { prognostic analysis framework to support utility implementation of online } \\
\text { monitoring for the component type. } \\
\text { (2018) Publish final guidelines to implement technologies for centralized } \\
\text { online monitoring and information integration. }\end{array}$ \\
\hline
\end{tabular}




\begin{tabular}{|c|c|}
\hline R\&D Area & Advanced II\&C Technologies \\
\hline $\begin{array}{l}\text { LTO - Centralized } \\
\text { Online Monitoring }\end{array}$ & $\begin{array}{l}\text { Milestones: } \\
\text { - (2012) Reactor building tendon monitoring feasibility study. } \\
\text { (2012) Integrate the diagnostic advisor and remaining-useful-life } \\
\text { prognostics applications and databases. } \\
\text { (2012) Complete software development and deliver the final version Asset } \\
\text { Fault Signature Database software. } \\
\text { (2012) Complete and publish the Bruce Power Maintenance Optimization } \\
\text { Monitoring application prototype results. } \\
\text { (2013) Report on results of cooperative research with industry partners to } \\
\text { expand research on (1) diagnostics R\&D, 2) industry database research to } \\
\text { support Asset Fault Signature Database signature capture, (3) develop } \\
\text { design-derived fault signatures to support Asset Fault Signature Database } \\
\text { selected components, (4) prognostics remaining-useful-life application and } \\
\text { database development. } \\
\text { (2013) Pilot applications of in-situ monitoring of material degradation of } \\
\text { passive assets. } \\
\text { (2014) Complete joint research on diagnostics and prognostics (remaining } \\
\text { useful life) application to critical plant assets. } \\
\text { (2015) Publish interim guidelines to implement technologies for centralized } \\
\text { online monitoring and information integration. } \\
\text { (2017) Complete transient analysis R\&D. } \\
\text { (2018) Publish final guidelines to implement technologies for centralized } \\
\text { online monitoring and information integration. }\end{array}$ \\
\hline $\begin{array}{l}\text { LWRS - Industrial } \\
\text { and Regulatory } \\
\text { Engagement }\end{array}$ & $\begin{array}{l}\text { R\&D Scope and Objectives: } \\
\text { Nuclear asset owner engagement is a necessary and an enabling activity to obtain } \\
\text { data and accurate characterization of long-term operational challenges, assess the } \\
\text { suitability of proposed research for addressing long-term needs, and gain access } \\
\text { to data and representative infrastructure and expertise needed to ensure success } \\
\text { of the proposed R\&D activities. Engagement with vendors and suppliers will } \\
\text { ensure that vendor expectations and needs can be translated into requirements } \\
\text { that can be met through technology commercialization. }\end{array}$ \\
\hline $\begin{array}{l}\text { LTO - Requirements } \\
\text { Database for } \\
\text { Advanced I\&C, } \\
\text { Human System } \\
\text { Interface, and } \\
\text { Information } \\
\text { Technology }\end{array}$ & $\begin{array}{l}\text { R\&D Scope and Objectives: } \\
\text { EPRI will develop a repository of advanced I\&C, human system interface, and } \\
\text { other information technology requirements and good practices from the pilot } \\
\text { studies and from other industry activities. The purpose of this repository is to } \\
\text { have a living resource for utilities to review the state-of-the-art and good } \\
\text { practices in the industry related to I\&C enhancement projects. }\end{array}$ \\
\hline $\begin{array}{l}\text { LWRS - Industrial } \\
\text { and Regulatory } \\
\text { Engagement }\end{array}$ & $\begin{array}{l}\text { Milestones: } \\
\text { - Included in discussion on "New Instrumentation and Control and Human } \\
\text { System Interfaces and Capabilities (including advanced II\&C pilot } \\
\text { projects)." }\end{array}$ \\
\hline
\end{tabular}




\begin{tabular}{|c|c|}
\hline R\&D Area & Advanced II\&C Technologies \\
\hline $\begin{array}{l}\text { LTO - Requirements } \\
\text { Database for } \\
\text { Advanced I\&C, } \\
\text { Human System } \\
\text { Interface, and } \\
\text { Information } \\
\text { Technology }\end{array}$ & $\begin{array}{l}\text { Milestones: } \\
\text { - } 2014,2016 \text {, and 2018)Releases of repository of advanced I\&C } \\
\text { requirements based on pilot studies within the advanced I\&C working } \\
\text { group, other industry pilot studies, and LWRS user facility results. }\end{array}$ \\
\hline
\end{tabular}

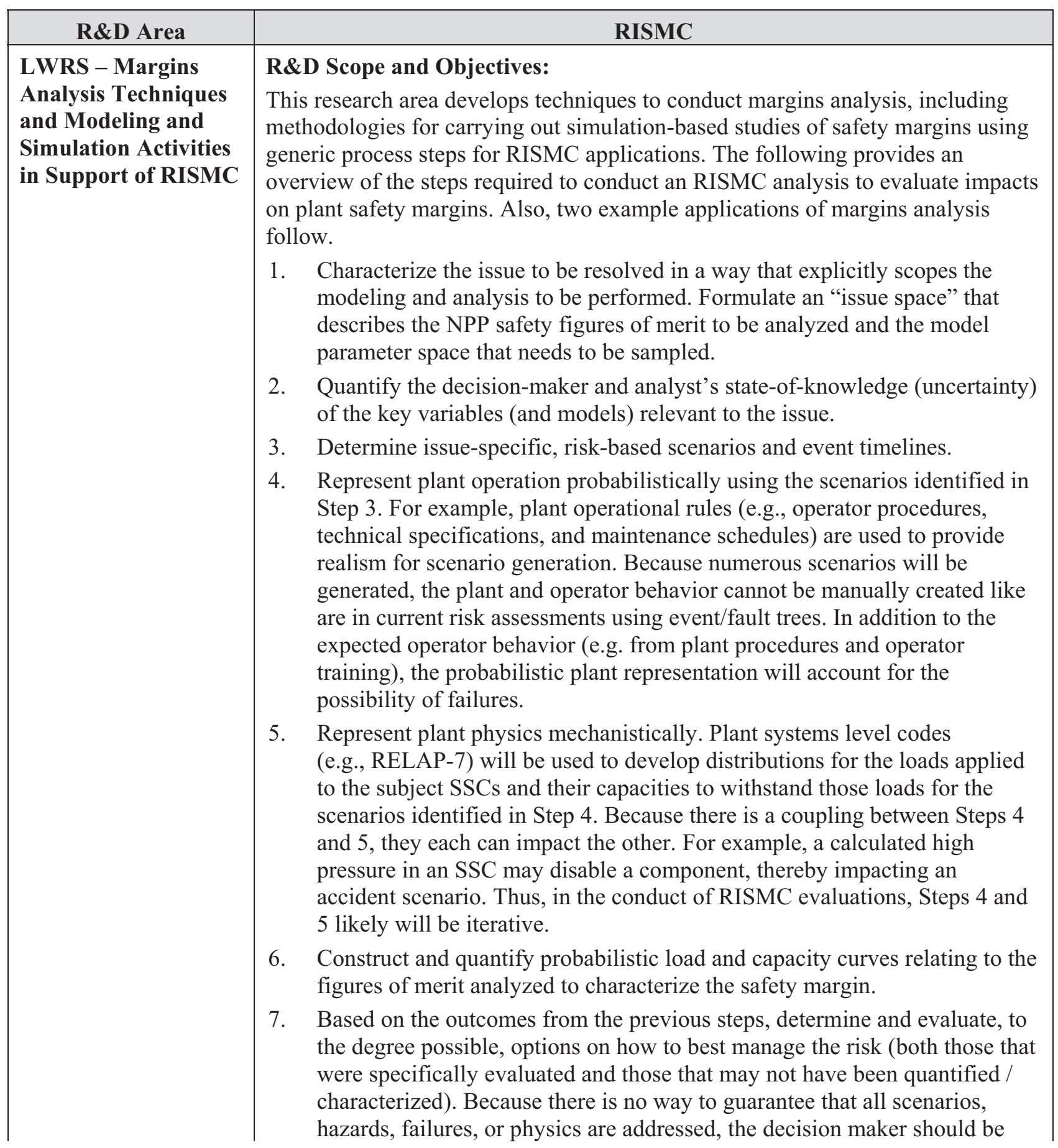




\begin{tabular}{|c|c|}
\hline R\&D Area & RISMC \\
\hline & 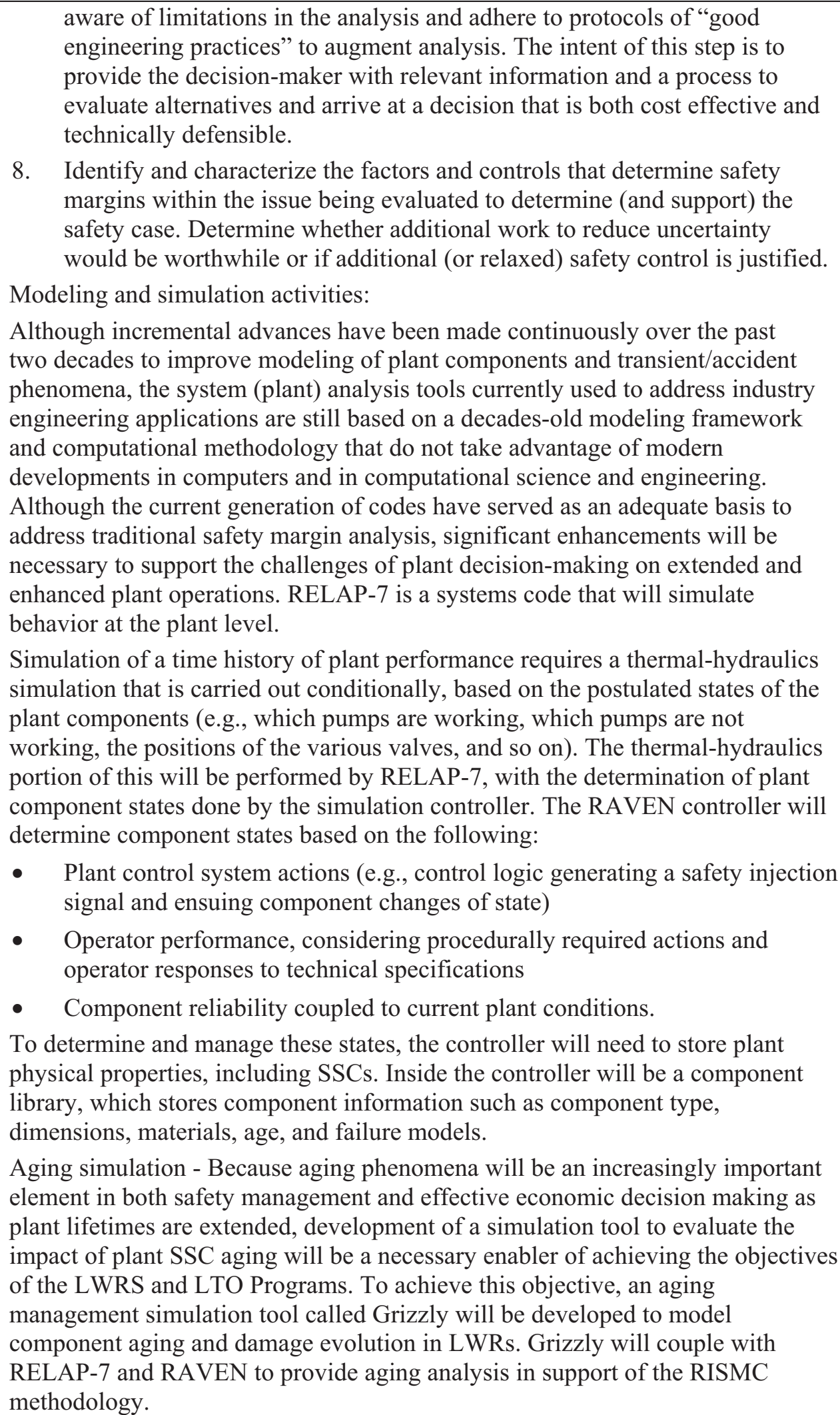 \\
\hline
\end{tabular}




\begin{tabular}{|c|c|}
\hline R\&D Area & RISMC \\
\hline $\begin{array}{l}\text { LTO - Enhanced } \\
\text { Safety Analysis } \\
\text { Capabilities }\end{array}$ & $\begin{array}{l}\text { R\&D Scope and Objectives: } \\
\text { To achieve successful long-term operations of the current fleet of operating } \\
\text { NPPs, it will be imperative that high levels of safety and economic performance } \\
\text { are maintained. Thus, operating NPPs will have a continuing need to undergo } \\
\text { design and operational changes, as well as manage aging degradation while } \\
\text { simultaneously preventing the occurrence of safety-significant events and } \\
\text { analytically demonstrating improved nuclear safety. This portion of the EPRI } \\
\text { LTO Program addresses two specific issues that are imperative to achieving } \\
\text { these objectives. } \\
\text { (1) First, as the current fleet of operational NPPs ages, it is anticipated that new } \\
\text { challenges to NPP safety will emerge. These challenges could be due to any } \\
\text { number of causes such as a change in regulatory policy or the occurrence of an } \\
\text { event at one or more operational plants. } \\
\text { (2) Second, as new technologies and capabilities become available, it will be } \\
\text { desirable to take advantage of these opportunities to enhance plant technical and } \\
\text { economic performance. Examples of such enhancements could include } \\
\text { performing extended power uprates or implementation of new technologies or } \\
\text { materials. } \\
\text { In each situation, a comprehensive and integrated assessment of the impact on } \\
\text { nuclear safety will be required to support effective and efficient decision making. } \\
\text { This research project will develop and validate an integrated framework and } \\
\text { advanced tools for conducting risk-informed assessments that enable accurate } \\
\text { characterization, visualization, and management of NPP plant safety margins. } \\
\text { This LTO task is intended to develop an integrated methodology to assess plant } \\
\text { safety margins and perform cost-effective risk-informed safety analyses to meet } \\
\text { these needs. It will achieve this objective by demonstration of effective and } \\
\text { efficient application of the RISMC approach to issues important to the long-term } \\
\text { operation of NPPs. This project also provides significant interface and } \\
\text { coordination of research efforts being conducted in safety analysis code } \\
\text { development and safety margin analyses being performed by INL as part of the } \\
\text { LWRS Program. }\end{array}$ \\
\hline $\begin{array}{l}\text { LWRS - Margins } \\
\text { Analysis Techniques } \\
\text { and Modeling and } \\
\text { Simulation Activities } \\
\text { in Support of RISMC }\end{array}$ & $\begin{array}{l}\text { Milestones: } \\
\text { - (2012) Deliver software development and quality assurance plans for } \\
\text { RELAP-7. } \\
\text { (2012) Demonstrate the RISMC approach using a test case based on the } \\
\text { INL Advanced Test Reactor. } \\
\text { (2012) Assist EPRI in defining the station blackout conditions for a } \\
\text { postulated event in a boiling water reactor with analysis focusing on the } \\
\text { impact on safety margins associated with an extended power uprate. } \\
\text { (2013) Develop a reactor loop capability in RELAP-7 for two-phase flow, } \\
\text { including the representation of several simplified major physical } \\
\text { components for a boiling water reactor's primary and safety systems. } \\
\text { (2013) Demonstrate RELAP-7's capability to simulate boiling water reactor } \\
\text { station blackout with the RAVEN system controller. } \\
\text { (2013) Deliver the RELAP-7 verification and validation plan. }\end{array}$ \\
\hline
\end{tabular}




\begin{tabular}{|c|c|}
\hline R\&D Area & RISMC \\
\hline $\begin{array}{l}\text { LTO - Enhanced } \\
\text { Safety Analysis } \\
\text { Capabilities }\end{array}$ & 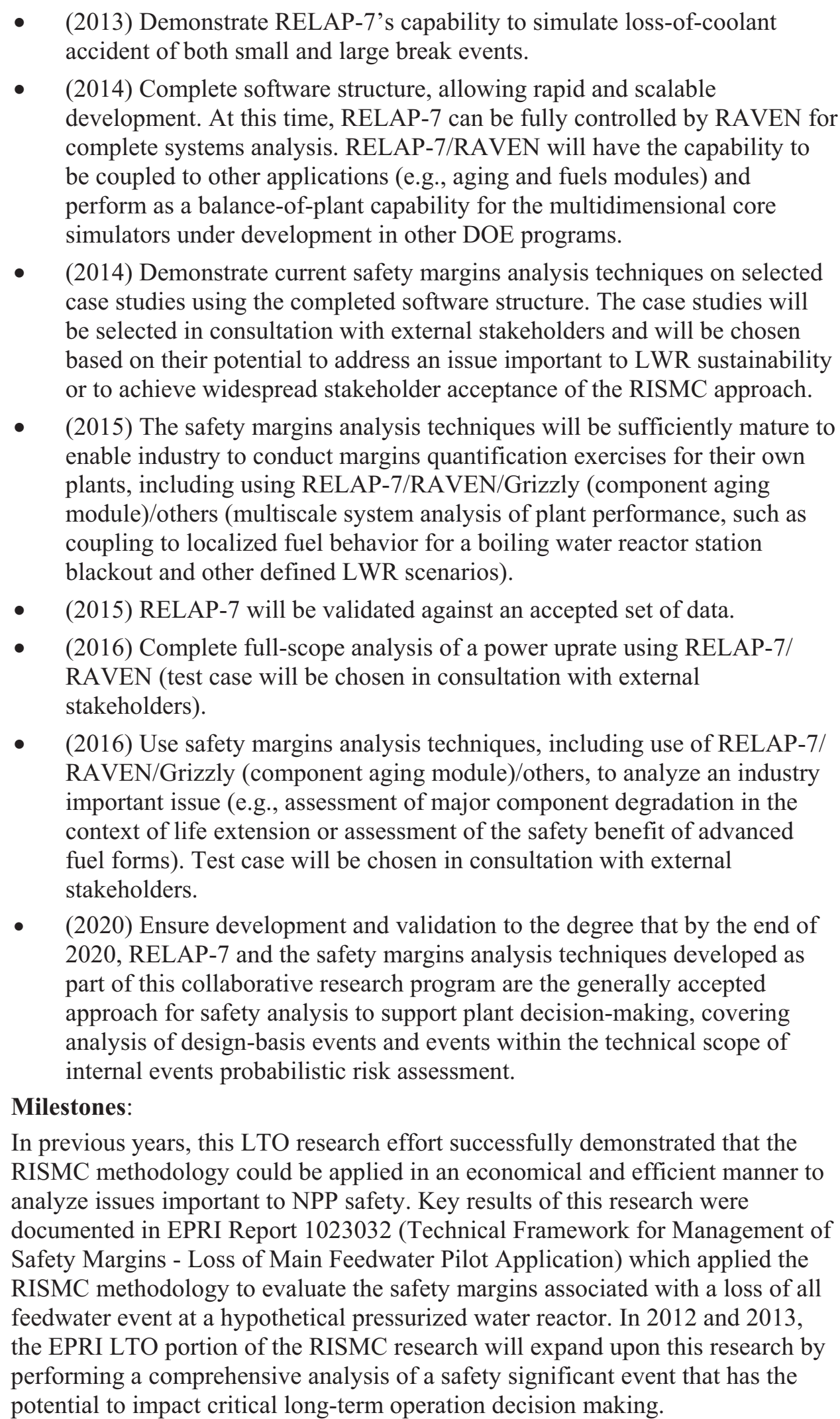 \\
\hline
\end{tabular}




\begin{tabular}{|c|c|}
\hline R\&D Area & RISMC \\
\hline & 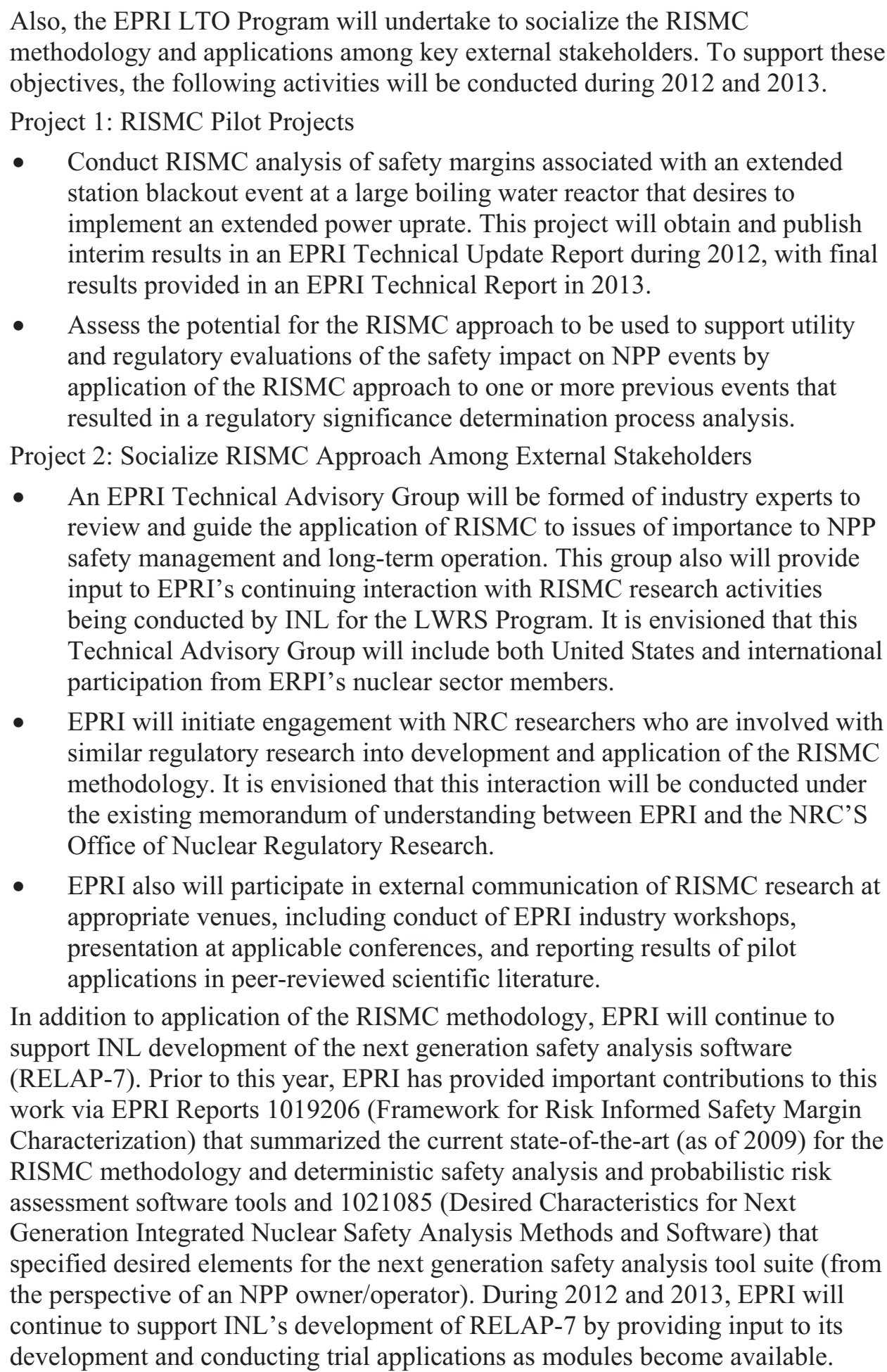 \\
\hline
\end{tabular}




\begin{tabular}{|c|c|}
\hline R\&D Area & RISMC \\
\hline & $\begin{array}{l}\text { Project 3: RISMC Safety Margin Method and Tool Development (LWRS) } \\
\text { - Support development of RELAP-7 by closely working with the INL } \\
\text { RELAP-7 development team to provide input to the software development } \\
\text { and conducting testing on trial safety analysis applications as modules } \\
\text { become available. In particular, it is intended that the RELAP-7 software } \\
\text { will be applied to support/confirm results from RISMC analysis of the } \\
\text { station blackout event for a boiling water reactor, with an extended power } \\
\text { uprate being conducted by EPRI during } 2012 \text { to } 2013 \text {. }\end{array}$ \\
\hline
\end{tabular}

